\title{
Corden
}

\section{Människohandel och arbetsliv}

Rapport från nordisk konferens 27-28.11.2012 i Helsingfors, Finland
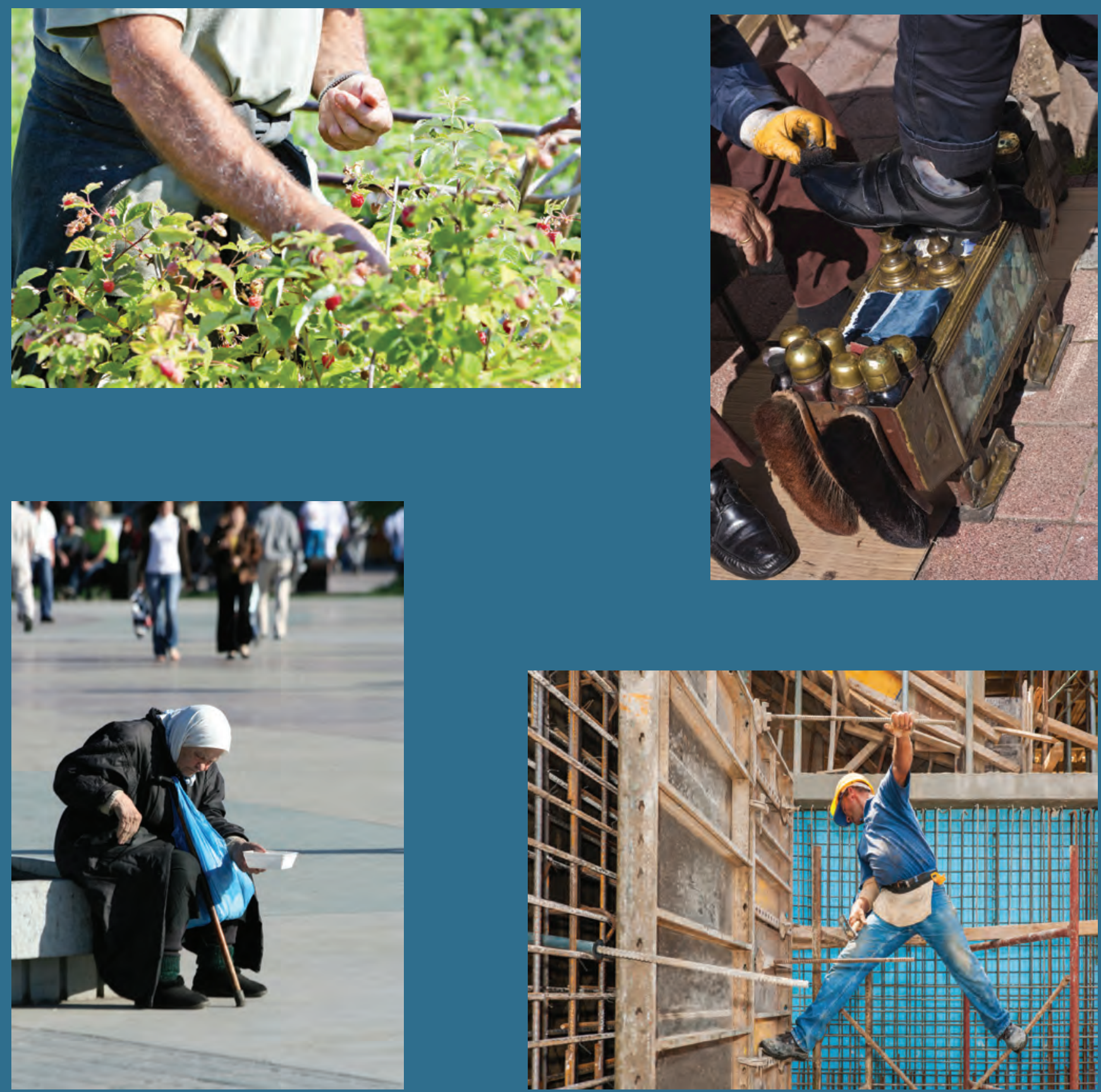

4 norden 



\section{Människohandel och arbetsliv}

Rapport från nordisk konferens 27-28.11.2012 i Helsingfors, Finland 
Människohandel och arbetsliv

Rapport från nordisk konferens 27-28.11.2012 i Helsingfors, Finland

ISBN 978-92-893-2590-5

http://dx.doi.org/10.6027/TN2013-554

TemaNord 2013:554

(C) Nordiska ministerrådet 2013

Layout: Hanne Lebech

Omslagsfoto: ImageSelect

Foto: Matti Keränen

Denna rapport är utgiven med finansiellt stöd från Nordiska ministerrådet. Innehållet i rapporten avspeglar inte nödvändigtvis Nordiska ministerrådets synpunkter, åsikter eller rekommendationer.

www.norden.org/sv/publikationer

\section{Det nordiska samarbetet}

Det nordiska samarbetet är ett av världens mest omfattande regionala samarbeten. Det omfattar Danmark, Finland, Island, Norge och Sverige samt Färöarna, Grönland och Åland.

Det nordiska samarbetet är politiskt, ekonomiskt och kulturellt förankrat och är en viktig partner i europeiskt och internationellt samarbete. Den nordiska gemenskapen arbetar för ett starkt Norden i ett starkt Europa.

Det nordiska samarbetet ska stärka nordiska och regionala intressen och värderingar i en global omvärld. Gemensamma värderingar länderna emellan bidrar till att stärka Nordens ställning som en av världens mest innovativa och konkurrenskraftiga regioner.

Nordiska ministerrådet

Ved Stranden 18

DK-1061 København K

Telefon (+45) 33960200

www.norden.org 


\section{Innehåll}

Sammanfattning.

1. Öppningsanföranden..............................................................................................

1.1 Människohandel - vad är tvång, vad är utnyttjande?.................................... 12

2. Session I Rekrytering av arbetskraft till Norden........................................................ 15

2.1 Rekrytering av sjukskötare till Ullevål sjukhus i Oslo................................... 16

2.2 Utländska bärplockare i Finland .................................................................... 17

2.3 Människohandel bland au pairs och i städbranschen - risker,

rekrytering och mellanhänder............................................................................ 18

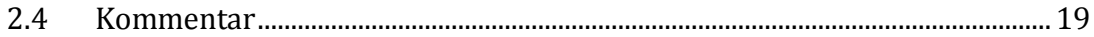

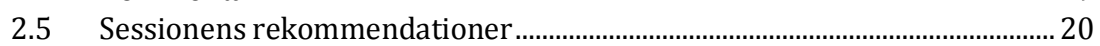

3. Session II Människohandel och utnyttjande av arbetskraft i Norden....................... 21

3.1 Människohandelns finansiärer - Skats insatser mot

människohandel............................................................................................ 22

3.2 Fackets insatser att bekämpa människohandel på

arbetsmarknaden i Norden................................................................................. 23

3.3 Utnyttjande av utländsk arbetskraft i Finland ur ett arbetarskydd

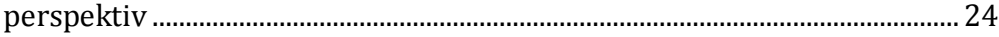

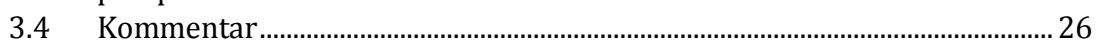

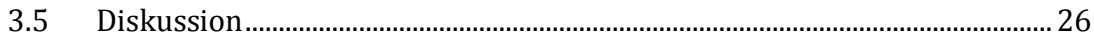

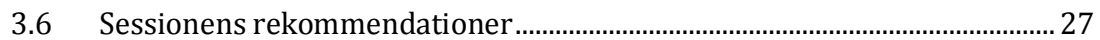

4. Session III Rättsliga processer .............................................................................. 29

$4.1 \quad$ Norska rättsfall - samarbete mellan åklagare och polis.................................. 30

4.2 Människohandel med bärplockare - rekrytering av bärplockare till

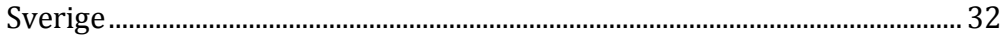

4.3 Arbetsrelaterad människohandel - utmaningar i förundersökning och process sett med åklagarens ögon ............................................................ 34

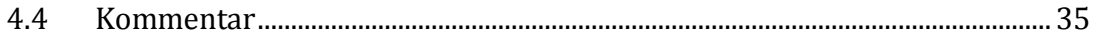

4.5 Diskussion ...................................................................................................... 35

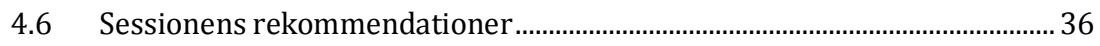

5. Session IV Lever Norden som den lär?...................................................................... 37

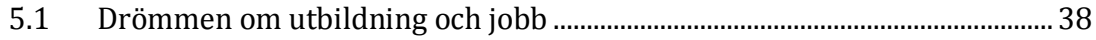

5.2 Vem kommer till Sverige för att jobba? ............................................................. 38

5.3 Reflektionsperioder för människohandelsoffer - erfarenheter från

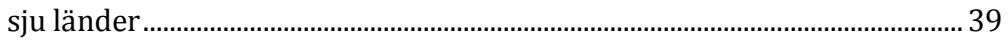

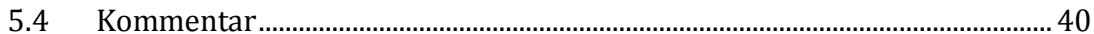

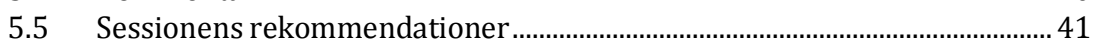

6. Session V Paneldiskussion Samarbete över gränser................................................... 43

7. Uppsummering och avslutning...................................................................................... 47 
8. Sammanfattning av rekommendationerna

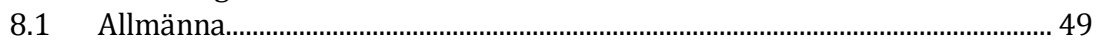

8.2 Rekrytering och övervakning …….......................................................... 50

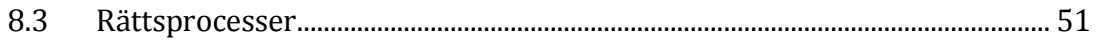

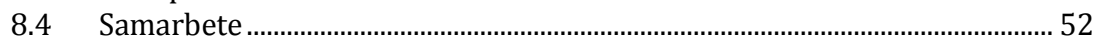

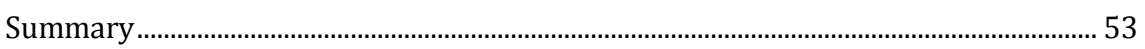

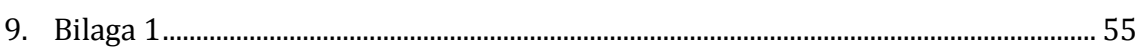




\section{Sammanfattning}

Den nordiska konferensen om Människohandel med fokus på arbetsliv arrangerades i Helsingfors, Finland den 27-28.11.2012. På konferensens diskuterades problemställningar som är kopplade till människohandel i arbetslivet ur ett tvärsektoriellt perspektiv. Målet var att förmedla information om olika aktörers kunnande, roller, ansvar och förmåga att identifiera och hantera problemen kring arbetsrelaterad människohandel.

Största utmaningen för de olika aktörerna i Norden idag är att identifiera de personer, kvinnor, män, flickor och pojkar, som är offer för arbetsrelaterad människohandel. Det är viktigt att offren erhåller information om sina rättigheter och om de sociala tjänster som finns tillgängliga för dem. På konferensen presenterades praktiska exempel på hur de nordiska länderna, polisen, åklagare, domstol, arbetarskyddsförvaltning, arbetsmarknadsparter och NGOs arbetar med människohandel kopplat till arbetsmarknaden i Norden.

Konferensens utgångspunkt var de resultat och erfarenheter från projekt och konferenser, som genomförts kring prolemställningar om människohandel och arbetsliv under de senaste åren i Nordiska ministerrådet och av myndigheter och organisationer i Norden.

Frågeställningar, som diskuterades på konferensen var:

- Vad är skillnaden mellan att bli tvingad att arbeta och de dåliga arbetsvillkor, som en del invandrare hamnar i?

- Vad är den största utmaningen gällande identifieringen av offer för människohandel inom arbetsmarknaden?

- Vad kan arbetarskyddet bidraga med?

- Hur kan samarbetet mellan myndigheter och arbetsmarknadens parter effektiveras? Vilka är de största utmaningarna?

- Är de sociala tjänsterna anpassade till offrens behov?

- Vad uppnås genom ett nordiskt samarbete? 
Under konferensen arrangerades:

- en öppningssession

- fyra tema sessioner:

Till Norden - rekrytering av arbetskraft, Människohandel - utnyttjande av arbetskraft i Norden, Rättsliga processer - människohandel och

arbetsliv och Lever Norden som den lär?

- en paneldiskussion.

Konferensen avslutades med en sammanfattning av minoritetsombudet Eva Biaudet.

Alla talare under sessionerna och deltagarna i paneldiskussionen skulle presentera rekommendationer om vilka åtgärder och insatser, som behövs i framtiden för att bekämpa människohandel. Rekommendationerna finns i samband med de enskilda presentationerna och i slutet av konferensrapporten finns en sammanfattning av de rekommendationer som presenterades under konferensen.

Konferensen samlade ett stort antal deltagare från olika länder och organisationer. Sammanlagt deltog ca 260 personer i konferensen. Deltagarna kom från alla de nordiska länderna samt de baltiska länderna och NV Ryssland. Utav dessa var ca 70 poliser eller gränsbevakare. Övriga grupper som var representerade var politiker, internationella organisationer, åklagare, migrationsmyndigheter, arbetarskyddsmyndigheter, arbetsmarknads-organisationer, medborgarorganisationer och forskare.

Konferensen arrangerades av Minoritetsombudet i Finland, som också är nationell rapporteur för människohandel i Finland. Konferensen finansierades av Nordiska ministerrådet i samfinansiering av Minoritetsombudet i Finland och Nordiska rådet. 


\section{1. Öppningsanföranden}

\section{Minister Anna-Maja Henriksson, Justitieministeriet, Finland}

Justitieminister Anna-Maja Henriksson betonade att människohandel är ett brott som allvarligt kränker en människas grundläggande rättigheter och att det därför är viktigt att utbyta erfarenheter mellan övriga nordiska aktörer. Människohandel är inte ett nytt fenomen, men att kampen mot människohandel lyckligtvis tagit alldeles ny fart under detta årtusende. De nordiska länderna har tagit sitt ansvar och varit aktiva i kampen mot människohandel.

Trots att det är viktigt att samarbeta på nordiskt plan så bör man inse att de viktigaste åtgärderna mot människohandel skall tas på det nationella planet. För detta behövs en nationell människohandelsrapportör samt en instans som på det operativa planet koordinerar de nationella insatserna.

För att ställa människohandlarna till svars och skydda offren uppmanade Henriksson till modigare inledning av brottsutredningar om människohandel och betonade att det kan finnas rent nationella fall av människohandel trots att merparten av fallen är gränsöverskridande.

För att förbättra identifieringen av människohandelsoffer poängterade Henriksson myndigheters ansvar. I detta sammanhang lyfte Henriksson upp arbetarskyddets verksamhet och resurser samt arbetet och informationsförmedlingen mellan olika myndigheter som viktiga samarbetsområden. Som en förutsättning för förbättrad identifiering av människohandelsoffer påpekade Henriksson att offrens och alla vittnens säkerhet måste proriteras. För detta är det viktigt att ha ett fungerande hjälpsystem så att offren kan frigöra sig den brottsliga verksamheten och från de kriminella personer som utnyttjat dem.

Minister Anna-Maja Henriksson var på grund av sjukdom förhindrad att delta och hennes öppningsanförande framfördes av specialmedarbetare Robin Harms. 


\section{Generalsekreterare Halldór Ásgrímsson, Nordiska ministerrådet}

Generalsekreterare Halldór Ásgrímsson inledde sitt tal genom att säga att människohandel är ett brott mot de mänskliga rättigheterna och drabbar de mest sårbara samhällsgrupperna. Ásgrímsson betonade att Norden inte är ett undantag när det gäller förekomsten av människohandel och konstaterade att det är en skam för Norden att människohandel och exploatering av arbetskraft pågår i de nordiska länderna. Däremot är, sade Ásgrímsson, tvångsarbete ett relativt nytt fenomen i Norden, vilket medför ett stort behov av tilläggskunskap och uppmärksamhet kring problemet. Detta förutsätter att arbetsmarknaden och andra aktörer behöver aktivera sig.

Allt fler människor rör sig idag över gränserna i jakten på ett bättre liv. Som en orsak till detta nämnde Ásgrímsson den ekonomiska krisen, som gjort det allt svårare att få arbete och människor hamnar i fattigdom och bostadslöshet, och därmed ökar deras villighet att ta chansen och flytta för att få arbete.

Ásgrímsson sade att Nordiska ministerrådet har som mål att bekämpa alla former av människohandel. Ásgrímsson betonade vikten av ett starkt och koordinerat nordiskt samarbete. Det nordiska samarbetet har en lång tradition och grundar sig på gemensamma grundläggande värderingar. Nordiska ministerrådet arbetar för att förstärka det regionala samarbetet på ett nordiskt plan men även med de tre baltiska länderna och nordvästra Ryssland. Genom att involvera länder, organisationer och aktörer, som arbetar med att motverka människohandel vill man uppnå en bredare koordinering och kunskapsutbyte över gränserna. Enligt Nordiska ministerrådet är detta avgörande för att bekämpa gränsöverskridande kriminalitet. För detta ändamål är uppbyggnad av nätverk och samarbete av betydelse, och bör även omfatta internationella organisationer.

Generalsekreterare Halldór Ásgrimsson sade:

"Reelt kan vi kun komme problemet til livs, hvis vi alle bidrager og tager vores ansvar alvorligt. Vi har alle vores rolle at spille i forhold til at forebygge, støtte ofrene og retsforfølge bagmænd. Det er her også vigtigt at huske på at menneskehandel finder sted, fordi der er en efterspørgsel - især i de velstillede lande - som Norden er en del af." 
Bild 1. Generalsekreterare Halldór Ásgrímsson, Nordiska ministerrådet, minoritetsombudet Eva Biaudet, Finland, specialmedarbetare Robin Harms, Finland och seniorrådgivare Maria-Pia de Palo, Nordiska ministerrådet deltog $i$ öppningssessionen

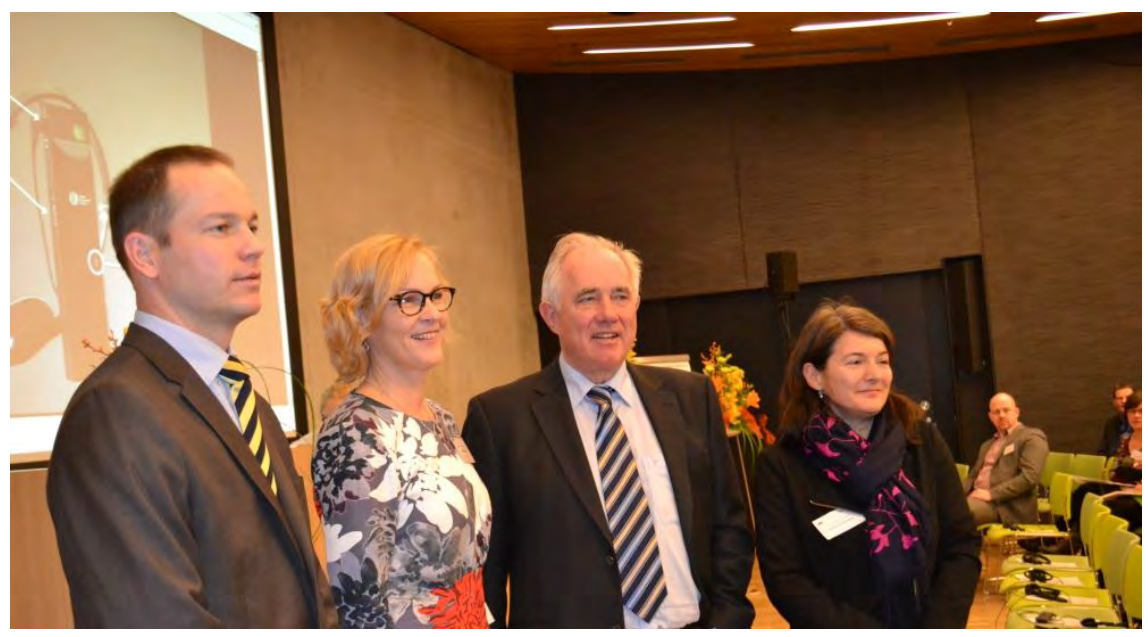

Fotograf: Matti Keränen

\section{Maria Stenberg, riksdagsledamot, Riksdagen, Sverige, medborgar- och konsumentutskottet, Nordiska rådet.}

Riksdagsledamot Maria Stenberg betonade i sitt öppningsanförande att människohandel är en kränkning av de mänskliga rättigheterna som måste tas på största allvar. För att effektivera bekämpningen av människohandel underströk Stenberg betydelsen av samarbete på såväl det nordiska planet som i hela Östersjöområdet.

Stenberg berättade att medborgar- och konsumentutskottet i Nordiska rådet har fokuserat på människohandelsfrågorna en längre tid och arbetat för att förbättra samarbetet i Norden och Östersjöområdet. Bekämpningen av människohandel förutsätter att arbetet är koordinerat. För detta ändamål är det politiska samarbetet viktigt.

Stenberg lyfte fram en rekommendation som år 2011 presenterats vid den parlamentariska Östersjökonferensen och som Nordiska rådet stöder. Enligt rekommendationen är det:

"viktigt att främja insatser för att skapa mer kunskap om människohandel för tvångsarbete, initiera och stödja utvecklingen av gemensamma strategier i samarbete med arbetsmarknadens parter och relevanta myndigheter, stärka de rättsliga och operationella medel att identifiera och bekämpa människohandel för tvångsarbete och genomföra informationskampanjer om människohandel för tvångsarbete." 
Stenberg betonade i sitt anförande vikten av att hela tiden följa upp nya trender och i allt större grad angripa problemen i förhand. De bakomliggande orsakerna till människohandel är många och komplexa, såsom fattigdom, konflikter, ojämn social fördelning och marginalisering. Detta kräver långsiktigt arbete. Insatserna för att bekämpa människohandel måste vara vittomfattande och förebyggande. Det är viktigt att människohandelsbrott utreds och att det finns ett hjälpsystem för offren. Stenberg avslutade med att betona det internationella engagemanget.

\subsection{Människohandel - vad är tvång, vad är utnyttjande?}

\section{Eva Biaudet, Minoritetsombud och nationell människohandelsrapportör, Finland}

Minoritetsombudet Eva Biaudet beskrev i sitt anförande mandatet, uppgifterna och sina erfarenheter som nationell människohandelsrapportör i Finland. För att arbetet mot människohandel skall vara effektivt betonade Biaudet att det är av största vikt att det borde finns en nationell rapportör för människohandel samt en kooridnator med ansvar för arbetet att motverka människohandel.

Biaudet konstaterade att människohandel finns även i Norden och att det kan förekomma på helt vanliga arbetsplatser var som helst i landet, överallt från landsbygden till huvudstaden. Oftast är offren utlänningar som av en orsak eller annan blir utnyttjade. Biaudet poängterade att förebyggande av människohandel främst bör fokusera på att minska invandrares utsatthet och genom att öka ansvaret för arbetslivet och genom att undersöka under vilka förhållanden arbetstagarna arbetar. Ju bättre en invandrare integreras och skapar sociala nätverk i ett samhälle ju mindre utsatt blir han eller hon.

Människohandel anses traditionellt vara organiserad brottslighet. Biaudet poängterade att idag även enskilda personer står bakom människohandeln. Det är inte ovanligt att gärningsmännen ofta är utlänningar, som har samma etniska bakgrund och som är släkt med offret. Den nära relationen fungerar som en bra hållhake på offren.

Biaudet konstaterade att ett av de största hindren för identifiering av människohandelsoffer är kulturen av misstro, det vill säga att inte tro att problemet existerar hos oss. Som den största utmaningen utpekade Biaudet våra egna attityder och vår egen bristande kunskap. 
Människohandel är ett fenomen, som lätt ändrar form och tar kontinuerligt nya metoder i bruk, och därför bör uppmärksamheten riktas mot indikatorerna för människohandel, i stället för bestämda definitioner.

Biaudet betonade att det är viktigt att organisera beviljandet av arbetstillstånd och uppehållstillstånd så att de inte tvingar en person i ett beroendeförhållande till arbetsgivaren och tvingar personen att stanna kvar i en situation av utnyttjande, inte ens ett lindrigt utnyttjande. Dessutom poängterade Biaudet att det är av största vikt att försäkra sig om att allvarliga brott mot invandrare, t.o.m. om de befinner sig i en s.k. irreguljär situation beträffande uppehållsstatus, alltid prioriteras framom mindre allvarliga förseelser eller förbrytelser som t.ex. inresan till landet

Biaudet betonade att våra samhällen har en skyldiget att skydda offer och vidta effektiva åtgärder för att hindra att människor blir offer för människohandel. Det innebär att:

"arbetstillstånden inte längre skall vara knutna endast till en viss arbetsgivare, och att arbetstagare som anställts av underleverantörer måste få namn, adress och kontakter till både arbetshälsovård och förtroendevalda. Företag som anlitar underleverantörer måste påläggas ett större ansvar och måste kontrollera att grundläggande arbetarskydd och arbetslivsregler efterföljs hos underleverantören. Skolor kan inte längre ha städerskor utan namn! Arbetarskyddet skall förbättra sitt samarbete med polis och arbetshälsovård. Hälsovården måste ta sitt ansvar för identifiering av offer och erbjuda offren hjälp."

Biaudet betonade alla parters ansvar att agera när man ser tecken på allvarlig exploatering av människor i arbetslivet. När människohandel väl har uppdagats följer en rättsprocess som tar lång tid och därför är det viktigt att minnas offrets behov av hjälp efter att hon eller han kommit bort från människohandlarens fysiska kontroll. Hjälpen skall inte heller vara beroende av en förundersökning. Det är viktigt att offrens rättigheter säkerställs efter straffprocessen, och att motverka att offret inte faller i händerna på människohandlarna på nytt. 



\section{Session I Rekrytering av arbetskraft till Norden}

Målsättningen med sessionen var att fokusera på bland annat följande frågor:

- Hur rekryteras arbetskraften? Hur ser processerna gällande rekryteringen ut?

- Vem sköter rekryteringen; enskilda personer, rekryteringsföretag, utländska eller inhemska?

- Var rekryteras arbetskraften, i hemlandet eller destinationslandet?

- Vilka åtgärder behövs i framtiden i Norden för att rekryterad arbetskraft inte skall bli offer för människohandel?

\section{Ordförande Anna Ekstedt, seniorrådgivare, Östersjöstaternas Råds Aktionsgrupp mot Människohandel (TF-THB CBSS)}

I sitt inledande tal presenterade seniorrådgivare Anna Ekstedt CBSS rapport Actions Against Trafficking for Labour Exploitation som är en kartläggning över de aktörer som har eller borde ha en roll i att bekämpa arbetsrelaterad människohandel i medlemsländerna. Enligt rapporten har de flesta av CBSS medlemsländer inte kommit så långt $i$ arbetet att bekämpa människohandel för arbetskraftsexploatering. Såväl brottsbekämpande, rättsvårdande och sociala aktörer saknar ofta både kunskap och verktyg i form av resurser och mandat för att effektivt bekämpa den här problematiken. En positiv utveckling enligt kartläggningen är att medvetenheten på såväl operativ som politisk nivå nu faktiskt börjar vakna till liv. 


\subsection{Rekrytering av sjukskötare till Ullevål sjukhus i Oslo}

\section{Polisinspektör Bjørn Vandvik, Utlendings- og forvaltnings- seksjonen, Oslo polisdistrikt, Norge}

Polisinspektör Bjørn Vandvik presenterade ett aktuellt fall som uppdagades i Norge under våren 2012. Det är frågan om filippinska sjukskötare som rekryterats till Ullevål sjukhus i Oslo via ett rekryteringsföretag. Rekryteringsföretaget skötte om bostad, språkundervisning och mat till sjukskötarna. Kostnaderna för detta drogs av från sjukskötarnas lön. Sjukskötarna fick inte gå ut och blev tillsagda att endast umgås med andra filippiner. Sjukskötarna hade varit tvungna att underteckna kontrakt med rekryteringsföretaget som innebar ett lån på upp till 300000 NOK för att täcka olika rekryteringskostnader. Rekryteringsföretaget anmäldes för människohandel, och dessutom anmälde Ullevål sjukhus rekryteringsföretaget för bedrägeri.

Vandvik lyfte fram att människohandel vanligtvis sker inom yrken som inte kräver formella kompetenskrav såsom inom bygg-, rengöring-, transport-, handels- och restaurangbranscherna och arbetet som au pair. Anmärkningsvärt i det norska sjukhusfallet är dock att det är fråga om ett yrke som är respekterat, har en god lön samt förutsätter språkkunskaper i norska och en yrkesutbildning, vilket offren hade.

\section{Rekommendationer}

- Förstå att tvångsarbete är en del av migrationsbrottslighet.

- Vara uppmärksam på indikatorer på människohandel.

- Övervakning och kontroll av arbetsplatser genom myndighetssamarbete för att öka risken av att bli avslöjad.

- Ansvaret hos den slutliga användaren av servicen bör stärkas och att bättre kontroll av rekryteringsfirmorna införs. 


\subsection{Utländska bärplockare i Finland}

\section{Forskare Pekka Rantanen, Tammerfors universitet, Tammerfors, Finland}

Forskare Pekka Rantanen från Tammerfors universitet presenterade forskning om thailändska bärplockare i Finland.

Bärplockarna rekryteras i Thailand av s.k. koordinatörer. Valet av bärplockare görs på tidigare års erfarenheter samt på basis av kön. Män har företräde eftersom de tål mer fysiskt arbete men man vill också undvika problem mellan könen i lägren och väljer därför män eller kvinnor, som är par eller har manliga släktingar i lägret. Koordinatorerna måste vara godkända av de thailändska myndigheterna. På deras verksamhet tillämpas dock inte lagstiftning gällande officiella rekryteringsföretag. Koordinatorn reser med bärplockarna till Finland och han/hon kan t.ex. vara lägerledare eller kartläggare av bärplockningsställen.

Bärplockarnas ekonomiska situation kan variera mycket beroende på om de äger mark eller inte i sitt hemland. Vissa kan t.o.m. vara ganska förmögna enligt thailändska normer. Koordinatorn kan vid behov ge lån till plockaren, vilket ofta leder till att bärplockaren måste återbetala sin skuld genom bärplockningen. Huruvida det är fråga om människohandel eller utnyttjande av arbetskraft beror främst på hur bärplockaren har finansierat sin bärplockningsresa. Beroendeförhållandet i människohandel uppstår genom låntagningen för rekryterings- och resekostnaderna.

En utmaning i identifiering av bärplockare som fallit offer för människohandel är att de arbetar isolerat från det övriga samhället. Eftersom bärplockarna inte är i ett arbetsförhållande, så övervakas de inte av myndigheterna i Finland. I Sverige däremot sker bärplockningen i arbetsförhållande vilket ger offret mer skydd. Denna skillnad framträder dock främst under dåliga skördeår. I Finland förutsätts numera en miniminettoinkomstnivå, vilket för Finland närmare den svenska modellen, men bärplockningen sker trots det fortfarande inte i ett arbetsförhållande.

\section{Rekommendationer}

- Bärplockarnas beroende av rekryteringsfinansieringen borde minskas. De verkliga inkomsterna och kostnaderna borde kunna följas upp och rekryteringskostnaderna borde inte få bli för höga. Risken borde fördelas jämnare mellan bärplockarna, rekryterarna och företagen, som köper upp bären.

- Myndigheterna borde övervaka finansieringen av bärplockningsresorna bättre. 
- Bärplockarna borde i sitt hemland informeras mera om bärplockningens villkor.

- Bättre samarbete mellan Finland och Thailand. Kontakten mellan Finlands ambassad i Bangkok och Thailands arbetsministerium är viktig för att motverka människohandel.

- Informationsutbyte och gemensamma spelregler är förutsättningen för att identifieringen av offren skall vara möjlig.

\subsection{Människohandel bland au pairs och $\mathrm{i}$ städbranschen - risker, rekrytering och mellanhänder}

\section{Antropolog, PhD-stipendiat Trine Mygind Korsby, Institut for Antropologi, Köpenhamns universitet, Köpenhamn, Danmark}

Forskare Trine Mygind Korsby presenterade de två undersökningar som hon utfört för Centret mod Menneskhandel i Danmark. Undersökningarna handlade om människohandel bland au pairs och i städbranschen. Undersökningarna riktades inte till fall där människohandel funnits utan fall där det funnits indikatorer på människohandel. Undersökningen lyfte upp några kritiska faktorer: skuldsättning, låg lön, långa arbetstider, inga lediga dagar, saknad av kunskap om rättigheter samt ett gen erellt behov av billig och flexibel arbetskraft inom dessa sektorer. Undersökningen kunde fastställa att arbetsgivarna eller rekryteringsföretagen har makten att hjälpa offren eller skada dem. Många arbetsgivare hjälper migranterna men många utnyttjar dem också. Många migranter var nöjda över sin situation och önskade att få hålla kvar sitt arbete, deras största rädsla var att mista jobbet. Några migranter önskade att arbeta extra mycket och bo i lite sämre förhållanden för att spara pengar vilket väckte frågan om var gränsen för utnyttjande av arbetskraft går. Arbetsgivarna eller rekryterarna upplevdes inte nödvändigtvis som "bad guys" utan de sågs ofta som hjälpande händer i en komplicerad migrationsprocess. Undersökningen kunde även fastställa att ju fler begränsningar det fanns för migrationen, desto större behov fanns det för en tredje part för att migrationen skulle lyckas. 


\section{Rekommendationer}

- Samarbete mellan relevanta aktörer på området (fackföreningar, privata sektorn, konsumenter).

- Fokus på nyanserna i debatten om människohandel. Det är inte alltid tydligt, svart-vitt, rätt-fel etc.

- Människohandel och utnyttjande av arbetskraft borde ses i ett sammanhang där lindrigt utnyttjande av arbetskraft finns i den ena ändan och allvarligt utnyttjande av arbetskraft i den andra ändan. Allt är inte människohandel, men alla bör se den risk det finns att en situation i ett senare skede kan utvecklas till människohandel.

\subsection{Kommentar}

\section{2:a ordförande Kyösti Suokas, Byggnadsförbundet, Finland}

2:a ordförande Kyösti Suokas konstaterade i sin kommentar att problemen uppkommer när det finns fattiga människor och för lite arbetsplatser. Suokas har i sitt arbete sett skillnader i hur européer och personer från tredje länder behandlas. Européer får ofta vad de har blivit lovade medan personer från tredje länder lättare blev lurade och utnyttjade. Suokas betonade att arbetet mot människohandel förutsätter mer än bara stickprov och kontroll från myndigheternas sida. Det förutsätter omfattande förändringar i myndigheters metoder och systemen för att komma åt den gråa ekonomin. Suokas poängterade även att det inte uppstår fler arbetsplatser bara genom att sänka lönen.

\section{Rekommendationer}

- Införa krav om att alla arbetare på arbetsplatsen skall bära id-kort med deras skattenummer.

- Flera parter måste samarbeta redan vid rekryteringen av arbetskraft (industri, fack, myndigheter).

- Kunskapen om arbetsrelaterad människohandel är för tillfället bristfällig, frågan måste prioriteras och kunskapen ökas. Detta förutsätter politisk vilja. 


\subsection{Sessionens rekommendationer}

- Behöver tvångsrekvisitet i Palermoprotokollet vara så starkt?

- Hela systemet för att bekämpa grå ekonomi måste utvecklas.

- Antalet enskilda kontroller/granskningar på arbetsplatser bör ökas.

- Skyldighet att bära ID-kort på byggarbetsplatser.

- Viktigt att kunna hjälpa offren och skräddarsy åtgärder för kvinnor och män. 


\section{Session II}

\section{Människohandel och utnyttjande av arbetskraft i Norden}

Målsättningen med sessionen var att fokusera på bland annat följande frågor:

- Vilka orsaker ligger bakom utnyttjandet?

- Varför utnyttjas arbetskraft? Vem blir utnyttjad?

- Hur tar utnyttjandet form? I hurudana förhållanden tvingas offren leva?

- Vad är det som gör utnyttjandet till människohandel?

- När är det fråga om arbetskraftsexploatering och när är det fråga om människohandel?

- Vilka åtgärder behövs för att arbetskraft inte i framtiden blir utnyttjad i Norden?

\section{Ordförande Maria Stenberg, riksdagsledamot, Riksdagen, Sverige, medlem i medborgar- och konsumentutskottet, Nordiska rådet}

Riksdagsledamot Maria Stenberg inledde den andra sessionen genom att lyfta fram vikten av samverkan mellan olika aktörer, både myndigheter och arbetsmarknadens parter samt internationella organisationer såsom FN, Europarådet, EU och den Internationella arbetsorganisationen (ILO). Stenberg poängterade även att på grund av de komplexa orsakerna till människohandel måste även insatserna för att bekämpa det vara många och vittomfattande. 
Bild 2. Deltagarna förbereder sig att lyssna på hur människohandel är kopplat till utnyttjande av arbetskraft i Norden

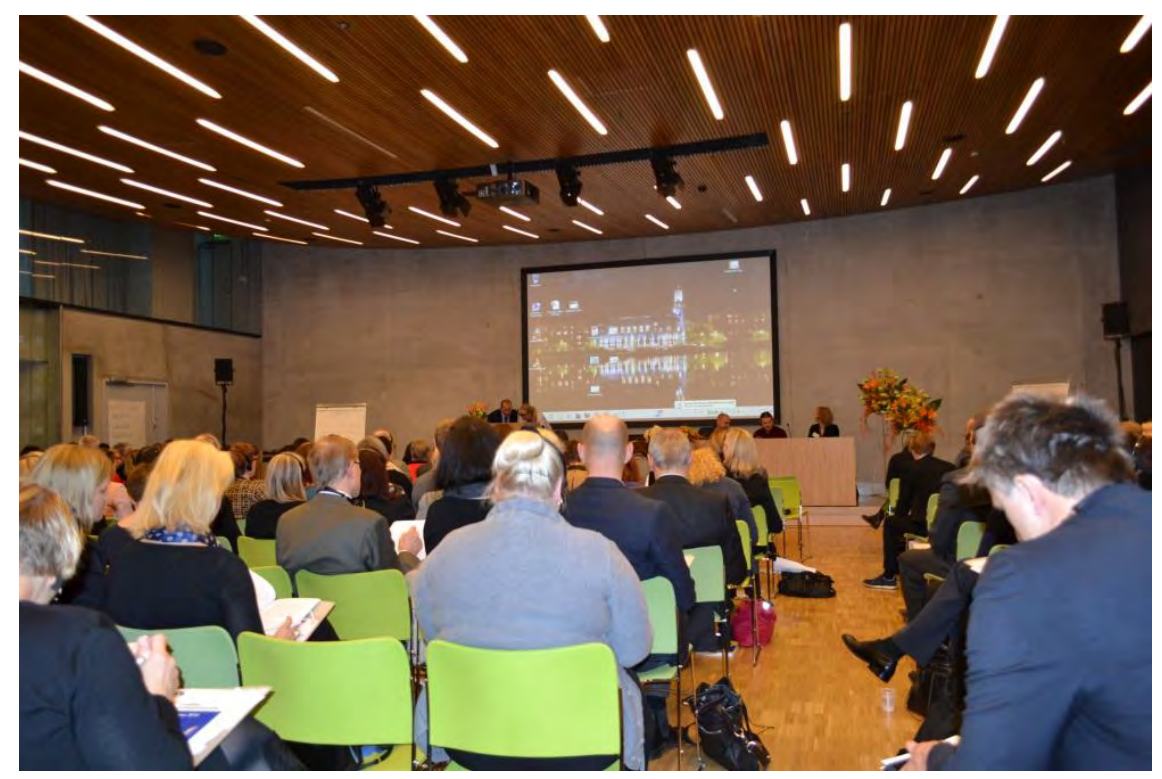

Fotograf: Matti Keränen.

\subsection{Människohandelns finansiärer - Skats insatser mot människohandel}

\section{Projektledare John Vorbeck Petersen, Økonomisk kriminalitet, Skat, Danmark}

Projektledare John Vorbeck Petersen från danska skattemyndigheternas enhet mot ekonomisk kriminalitet presenterade danska skattemyndigheternas projekt "Menneskehandelns bagmænd". Inom projektet samarbetar skattemyndigheterna med polisen, Centret mod Menneskehandel, arbetarskyddet och efter behov med andra parter som fackföreningar. Skattemyndigheternas roll i detta har varit att bidra med bl.a. ekonomiska upplysningar. Under projektet har Skat undervisat medarbetare om människohandel, sänt ut informationsmaterial, utvecklat nya verktyg, t.ex. intervjuscheman, och ingått samarbetsavtal med viktiga intressenter. 
Petersen betonade i sitt anförande att den grundläggande orsaken till utnyttjande av arbetskraft är pengar. Regler om t.ex. skatt är förhållandevis lätta att kringgå vilket människohandlarna utnyttjar. På grund av att offren kommer från dåliga förhållanden i hemlandet och har dåliga erfarenheter av myndigheters arbete önskar offren inte berätta om att de blir utnyttjade.

\section{Rekommendationer}

- Myndighetssamarbete både nationellt, nordiskt och internationellt.

- Synliga kampanjer. Erfarenheten har visat att då personer får kunskap om att människohandel förekommer och vilka konsekvenser det har för offren så finns också viljan att bekämpa det.

- Etablera nationella "task force".

- Utse en nordisk grupp för utbyte av erfarenheter.

\subsection{Fackets insatser att bekämpa människohandel på arbetsmarknaden i Norden}

\section{Migrationspolitisk expert Thord Ingesson, LO, Sverige}

Utredare Thord Ingesson konstaterade inledningsvis att utvidgningen av EU har märkbart påverkat människohandeln i Norden. Ingesson påpekade att människohandel är mera en polisiär fråga än en fråga för facket, men att även facket är inkopplat i och med att kollektivavtalen även gäller människohandelsoffer. Ingesson lyfte upp behovet av att agera förebyggande - påverka regelverket samt att utveckla myndighetssamarbetet. Det svenska arbetstillståndssystemet kallade Ingesson för en människohandlares dröm. År 2008 genomfördes en reform gällande arbetskraftsinvandring i Sverige, som underlättade rekryteringen av arbetskraft från tredje länder. Reformen medförde att arbetsförmedlingen inte längre prövar behovet av arbetskraften utan det är arbetsgivaren själv som utför denna behovsprövning. Ingesson konstaterade att det är lätt att komma in i Schengen området genom Sverige och att Sverige därmed blivit ett transitland.

Ingesson poängterade att den ekonomiska brottsligheten och vinsten är centrala bakgrundsfaktorer för människohandel. Syftet med att arbetskraft flyttas från ett land till ett annat land bl.a. genom "svartjobb" är att göra ekonomisk vinst. Ingesson poängterade även att människohandlarna ofta är multikriminella, och att de fungerar i kriminella nätverk. 
För att komma åt dem måste myndigheterna konfiskera pengarna och slå till mot etablerade brottsliga nätverk och förhindra att nya kriminella grupper etableras.

\section{Rekommendationer}

- Ökade insatser mot den ekonomiska brottsligheten.

- Insatserna bör inte koncentreras till att hitta och avslöja människohandel inne i ett enskilt land - utan det skall stoppas redan vid gränsen.

- Människohandlare är ofta multikriminella. Det är effektivt att gå efter pengarna och förhindra att att nya kriminella nätverk etableras.

- Stärka huvudentreprenöransvaret.

- Samarbete är en förutsättning. Människohandel är inte ett enskilt lands angelägenhet - enbart nationella åtgärder kan inte bekämpa människohandel.

\subsection{Utnyttjande av utländsk arbetskraft i Finland ur ett arbetarskydd perspektiv}

\section{Inspektör Kristiina Linna, Regionförvaltningsverket $i$ Sydvästra Finland, ansvarsområdet för arbetarskydd, Finland}

Inspektör Kristiina Linna presenterade sina erfarenheter som arbetarskyddsinspektör specialiserad i övervakning av användningen av utländsk arbetskraft i Sydvästra Finland. Orsakerna till utnyttjandet är svåra att definiera, det kan vara fråga om att offren inte känner till lagstiftningen eller kulturella skillnader. Linna nämnde att i Finland har hårt arbete alltid uppskattats och i jordbruket förväntas arbetstagarna att arbeta utan att utnyttja lediga dagar. Alla offer som Linna mött har haft uppehållstillstånd i Finland, så olovligt arbete är inte så typiskt i Finland. Linna poängterade att ett problem idag är att när myndigheterna upptäcker ett utnyttjande har det ofta lett till att offret inte beviljats fortsatt uppehållstillstånd. Det att arbetsgivaren inte följt finländska lagar och förordningar har alltså lett till att arbetstagaren utvisas från landet, och inte att arbetsgivaren straffas. 
Arbetarskyddsinspektörerna meddelar Migrationsverket och arbetsoch näringsbyråernas enheter för arbetstillstånd, kommunernas hälsooch byggnadsinspektörer samt skattemyndigheterna när de utför granskningar på arbetsplatser. Om inspektören misstänker att människohandel eller ockerliknande arbetsdiskriminering förekommer tar inspektören kontakt med polisen och hjälpsystemet för människohandelsoffer.

Linna konstaterade att förmågan att identifiera människohandelsoffer utvecklas i takt med att inspektören får mera erfarenhet. Inspektören lär sig att sköta fallen bättre, exempelvis så att inspektionen inte orsakar straffåtgärder åt arbetstagaren å arbetsgivarens vägnar. Arbetsgivaren kan nämligen ibland tro att det är arbetstagaren som kallat inspektören till arbetsplatsen. Ett exempel på en konkret och god praxis är att arbetarskyddet har kommit överens med polisen om att arbetsgivaren inte kallas till polisförhör innan offren tagits in i hjälpsystemet för människohandelsoffer.

Linna lyfte upp de allmänt bindande kollektivavtalen som en viktig del i bekämpningen av människohandel. Arbetsgivare som inte har avtal med en fackorgansation måste följa branschens allmänna kollektivavtal i förhållande till sina arbetstagare.

\section{Rekommendationer}

- Mera kunskap och utbildning av arbetarskyddsinspektörer, poliser, gränsbevakare och övriga myndigheter för att förbättra identifieringen av offer.

- Attitydförändring. Människohandel finns i Finland och Norden, vi har bara inte sett det tidigare. Men behåll en realistisk uppfattning och se inte människohandel överallt där det finns utländska arbetstagare.

- Regelbunden och omfattande övervakning av arbetsplatser också i förebyggande syfte. Under granskningarna kan inspektören upplysa arbetstagarna om lagar och kollektivavtal och om arbetstagarnas rättigheter och arbetsgivarens skyldigheter. 


\subsection{Kommentar}

\section{Direktör Jari Kähkönen, Hjälpsystemet för människohandelsoffer, Joutseno förläggning, Finland}

Direktör Jari Kähkönen beskrev i sin kommentar de stigande siffrorna över människohandelsoffer i Finland. I det finska hjälpsystemet finns för tillfället närmare 100 människohandelsoffer, och största delen är offer för arbetsrelaterad människohandel.

\section{Rekommendationer}

- Män och kvinnor behöver hjälp och tjänster av olika slag. Idag behövs det också hjälpsystem och tjänster som är riktade till män.

- Mera tillgänglig information om arbetstagarens rättigheter och skyldigheter i arbetsökarnas hemländer på arbetstagarnas språk, t.ex. då de ansöker om uppehållstillstånd.

- Mera utbildning för de personer som kan komma i kontakt med människohandelsoffer, t.ex. inom social- och hälsovården.

- Mer centraliserad och effektiverad myndighetsutredning av människohandelsfall, t.ex. genom att etablera en "task force".

- Minska efterfrågan.

- Åtrgärder för att offer inte på nytt blir offer för människohandel.

\subsection{Diskussion}

Diskussionen i den andra sessionen tog upp bland annat "beställarens" ansvar vid anlitande av utomstående arbetskraft. Detta gäller både dem som förmedlar bären och dem som i sista ändan köper bären. Thord Ingesson tog upp frågan om att huvudentreprenören även har ett ansvar att bekämpa människohandel. Huvudentreprenören har ansvar att övervaka vad som sker i kedjans andra ända vid användning av underleverantörer. Detta är en fråga som borde betonas starkare.

Vidare betonades myndigheternas ansvar att bedöma människohandelsoffrets situation. Ofta ser ett offer inte sig själv som ett offer. Viktigt är dock i sådana situationer att minnas att det är myndigheternas ansvar att utreda och avgöra om en person fallit offer för människohandel. Ansvaret får inte lämnas till offret eftersom offret är oförmöget att bedöma sin egen situation. 


\subsection{Sessionens rekommendationer}

- Mera samarbete på olika nivåer mellan alla involverade parter/myndigheter.

- Mera diskussion om uppehållstillstånd.

- Fler insatser mot ekonomisk brottslighet.

- Medborgarorganisationernas roll bör förstärkas. 



\section{Session III Rättsliga processer}

Målsättningen med sessionen var att fokusera på bland annat följande frågor:

- Vilka problem finns i rättsprocessen (förundersökning, åtal, domstolsbehandling) då det gäller arbetsrelaterad människohandel konkreta exempel på konkreta problem?

- Hur har dessa problem överkommits i de fall som förts till domstol eller hur har de inte överkommits?

- Hur ser ni på definitionen av arbetsrelaterad människohandel och gränsdragningen till andra liknande brott?

- Vad tycker ni är viktigt att i framtiden ta i beaktande för att arbetsrelaterad människohandel ska utredas, åtalas och dömas i större utsträckning än hittills?

\section{Ordförande Natalia Ollus, specialplanerare, Europeiska institutet för kriminalpolitik, verksamt i anslutning till Förenta Nationerna, HEUNI, Finland}

Specialplanerare Natalia Ollus betonade att människohandel inte skall ses som ett brott som sker vid en viss tidpunkt genom en viss handling utan människohandel är en process av utnyttjande. De metoder som används för att kontrollera en arbetstagare är väldigt finstilta. 


\subsection{Norska rättsfall - samarbete mellan åklagare och polis}

\section{Avsnittsleder Jarle Bjørke, BSP/Org.Krim Analyse \& Koordineringsavsnittet, Hordaland politidistrikt Bergen, Norge}

Avsnittsledare Jarle Bjørke inledde med att uppmana alla att bry sig om offren för människohandel. Endast om vi tar offren på allvar, kommer de att berätta oss sin historia. Bjørke lyfte fram några nyckelpunkter för framgång, som EXIT gruppen i Hordaland polisdistrikt i Bergen i Norge har funnit viktiga. Bjørke efterlyste bland annat engagerade förundersökningsmyndigheter. Man måste ha yrkeskunskap och förmåga att våga utmana den etablerade folkopinionen, våga utmana sin egen och sin kollegas "kultur" och de traditionella förundersökningsmetoderna. Dessutom måste en god förundersökningsmyndighet ha empati och respekt för offret.

Bjørke betonade även förundersökningsmyndigheternas samarbete med åklagaren. Åklagaren och polisen måste ha ett nära samarbete för att nå resultat. För EXIT-gruppen har det varit bra att åklagarens och polisens kontor fysiskt varit närbelägna. Bjørke påpekade att människohandel är ett område som alla jurister varken kan eller vill jobba med. I arbetet mot människohandel möter man flera utmaningar som man i annat polisarbete kan undgå, t.ex. kräver människohandel mera kreativitet och argumentering med personlig insats. Offren är personer som kommer från fattigare förhållanden och är mycket mer sårbara än de personer, som arbetarmed bekämpning av människohandel. Bjørke poängterade att god offerbehandling är en god investering. Hjälp till offren genom ett hjälpsystem är avgörande för polisens arbete att undersöka fallet och föra det vidare till domstol. Ett fungerande hjälpsystem minskar den fysiska och psykiska påfrestning som en förundersökning och rättegång orsakar offret. Under en förundersökning av människohandel är det viktigt att minnas att människohandlarna hela tiden ändrar och utvecklar sina arbetsmetoder. Förundersökningsmyndigheterna måste därför handla snabbt.

I rättegångarna har EXIT-gruppen använt expertvittnen, som är lokala, nationella och internationella sakkunniga i människohandel, och som kan ge domstolen en faktabaserad beskrivning av människohandel. Samarbetet mellan polis, åklagare och expert vittnet är viktigt för en god domstolsprocess. 
Bjørke nämnde social dumpning som en orsak till människohandel eftersom en person som hamnar i en sårbar situation är ett lätt offer för människohandel. Bjørke tog upp kostnadsfrågorna som dyker upp i samband med människohandelsutredningar och han poängterade att eftersom vi i Norden är tillräckligt rika för att utnyttja ett offer, är vi nog också tillräckligt rika för att hjälpa personen ifråga. Med respekt för människovärdet och de mänskliga rättigheterna är det en god investering att bekämpa människohandel och hjälpa offret i en straffprocess som leder till att ärendet kan slutbehandlas på kortare tid och som samtidigt sparar pengar.

\section{Rekommendationer}

- Inrättas specialiserade förundersökningsmyndigheter för människohandel.

- Ett nära samarbete mellan åklagare och polis.

- Låg tröskel för att förnya verksamheten och strategierna.

- Användning av expert-vittnen under rättegången.

- Förebyggande arbete på arbetsplatser, skolor och företag.

- God dokumentation av den sårbara situation som offret befinner sig i eller kommer från.

- Utveckling av hjälpsystemet för offer.

- Respekt av människovärdet och de mänskliga rättigheterna i behandlingen av offret.

- Enklare regelverk för arbetsinvandringen.

- Införande av minimilön.

- Bättre informering av arbetstagarnas rättigheter, i synnerhet för arbetsinvandrare.

- Beskrivning av begreppet social dumpning.

- Förstärkning av arbetarskyddets övervakning.

- Bättre uppföljning av offrens situation.

- Flera kontroller och mera insatser mot oseriösa arbetsgivare.

- Arbetarskyddet och polisen skall utföra mer uppsökande arbete för att identifiera offer.

- Sänka tröskeln för anmälning till polisen. 
- Tvärsektoriell informationsdelning och dokumentation.

- Snabbare förundersökningar.

- Kom ihåg: "I will only tell my story if you care about it."

\subsection{Människohandel med bärplockare - rekrytering av bärplockare till Sverige}

\section{Kammaråklagare Christina Voigt, Internationella åklagarkammaren, Stockholm, Sverige}

Kammaråklagare Christina Voigt presenterade fall av människohandel om bärplockare från Bulgarien som rekryterades till Sverige under år 2010 och 2011. Många av bärplockarna kontaktade polisen för att de blivit lurade av sina bossar för att de inte fått betalt eller blivit illa behandlade. Alla bärplockare berättade oberoende av varandra exakt samma historia. Första åtalen väcktes år 2011 om att bärplockarna hade blivit utsatta för människohandel med syfte att tvinga dem att plocka bär. Rätten ansåg inte att Voigt kunde bevisa att syftet varit att utnyttja bärplockarna för tvångsarbete. Två bossar dömdes för att de hotat, misshandlat och tagit bärplockarnas pass. Dessa fall fick mycket uppmärksamhet i medierna.

Följande fall gällde 13 bärplockare som under tre tidsperioder varit i Sverige under två år, och som bott under usla förhållanden och som inte hade fått betalt. Voigt ställde frågan: Hade dessa bärplockare helt enkelt ingått usla avtal eller var de offer för människohandel.

Lagstiftningen i Sverige om människohandel innehåller många olika moment och alla moment måste vara uppfyllda för att en handling ska kunna anses vara människohandel. Vad gäller lagstiftningens krav ansåg Voigt att alla moment i dessa fall var uppfyllda. Bärplockarna hade rekryterats, transporterats och även blivit inhysta i Sverige, blivit vilseledda, och att bossarna både i Bulgarien och i Sverige utnyttjat deras utsatta belägenhet. Eftersom detta drabbat så många bärplockare, oberoende av varandra, under olika perioder så menade Voigt att syftet att de skulle utnyttjas för tvångsarbete också var uppfyllt.

Det största problemet för att kunna skilja ett dåligt avtal och människohandel ansåg Voigt vara att kunna visa att människohandlarna använt ett s.k. otillbörligt medel. Ett krav som den svenska lagen kräver. Ett s.k. otillbörligt medel innebär att människohandlare antingen hotat, misshandlat eller vilselett sitt offer eller utnyttjat offrets utsatta belägenhet. Att bevisa användningen av ett otillbörligt medel är även den 
största utmaningen i människohandelsfall. I fallet med bärplockarna var ett av problemen att bärplockarna var analfabeter, att de inte kunde klockan och inte kunde räkna. Det blev svårt att få ett vittnesmål av bärplockarna, för att styrka att de blivit vilseledda, och tingsrätten ansåg inte att Voigt kunde styrka att bärplockarna hade blivit vilseledda. Däremot ansåg tingsrätten att bossarna utnyttjat bärplockarnas utsatta belägenhet och dömde därför för människohandel. Domen för fallet har överklagats och har inte ännu prövats i hovrätten i Sverige.

Voigts slutsats är att det i princip är omöjligt att visa att någon blivit vilseledd när det gäller legalt arbete, det är helt enkelt bara ett dåligt avtal. Men om man granskar vem och vilken målgrupp det är som ingått ett dåligt avtal, så ser man att det rör sig om ytterst fattiga människor som sätts i skuld, och som helt saknar omvärldskunskap, som inte har språkkunskaper, som är fråntagna sina resedokument och som är utan pengar. personerna befinner sig helt enkel i en sådan utsatt belägenhet att det är just dessa personer som kan utnyttjas för tvångsarbete.

Voigt avslutade med att säga att hon hoppas att man nu i Sverige har fătt ett redskap för att identifiera arbetsrelaterad människohandel. Det är viktigt att kunna identifiera problemet i hela kedjan från polis, sociala myndigheter, åklagare och även till domare.

\section{Rekommendationer}

- Lära sig identifiera människohandel.

- Vara lyhörd på vad offren berättar. Berättar de samma historia bildar det ett mönster som är människohandel.

- Samarbete i Norden för att utbyta information mellan åklagare som arbetar med människohandel.

- Våga ta itu med problemet och ge inte upp trots att processen är svår och tung. 


\subsection{Arbetsrelaterad människohandel - utmaningar i förundersökning och process sett med åklagarens ögon}

\section{Ledande häradsåklagare Peter Levlin, Åklagarämbetet $i$ Österbotten, Finland}

Ledande häradsåklagare Peter Levlin berättade om sina erfarenheter av människohandel vid åklagarämbetet i Österbotten. För tillfället fanns det fem anhängiga ärenden i vilka åtal väckts för människohandel, alternativt ockerliknande diskriminering i arbetslivet eller grovt ocker. Detta var förhållandevis många fall i jämförelse med situationen i övriga Finland.

Levlin sade att i de för tillfället anhängiga ärendena hade fallen kommit till myndigheternas kännedom genom att något av offren blivit utsatt för våld och sökt skydd hos myndigheterna. Endast ett av ärendena hade kommit fram genom regelmässig övervakning, och därför betonade Levlin behovet av att utveckla övervakningen och granskningen på arbetsplatserna.

Levlin sade att polisen under årens lopp klart utvecklat sin kunskap och sina processer om hur man identifierar och bemöter eventuella offer för människohandel. Levlin såg inledningen av förundersökningen som ett kritiskt skede och viktigt för att lyckas bygga upp ett förtroende mellan offer och myndighet. Förtroendet är en förutsättning för en lyckad förundersökning eftersom många offer inte har helt positiva erfarenheter från samarbete med myndigheterna i sina hemlander.

Levlin konstaterade att även om man lyckades bygga upp ett förtroende mellan offer och myndighet och bryta kontakten till gärningsmannen finns det ändå sätt för gärningsmannen att komma åt offren, t.ex. genom att gärningsmannens samarbetspartners i hemlandet utför påtryckning på offrets anhöriga. I dessa fall kan myndigheterna givetvis utreda och även åtala för hotelserna eller försöken att påverka. Levlin efterlyste bättre samarbete mellan myndigheter i Finland och de länder som arbetstagare rekryteras från.

\section{Rekommendationer}

- Utveckling av myndighetsövervakning och arbetarskyddets granskningar.

- Viktigt att bygga upp ett förtroende mellan offer och myndighet genast från början. 
- Viktigt att genast isolera gärningsmannen och de eventuella offren från varandra, med hjälp av hjälpsystemet för människohandelsoffer eller genom att begära gärningsmannen häktad.

- Bättre samarbetsavtal mellan länderna rättshjälp.

- Införa använding av simultantolkningen under rättegångar för att förkorta behandlingstiden.

\subsection{Kommentar}

\section{Distrikt poliskommissarie Sigríður Björk Guðjónsdóttir, Suðurnes polisdistrikt, Island}

Distrikt poliskommissarie Sigríður Björk Guðjónsdóttir lyfte i sin kommentar upp offrets förtroende till myndigheterna som en nyckelpunkt. Det är viktigt att försäkra vittnesskyddet för att förundersökningen skall ha framgång. Guðjónsdóttir betonade även behovet av att följa upp den brottsliga verksamhetens penningflöde som ett verktyg för att utreda och bekämpa människohandel. Ett nordiskt samarbete är ett bra sätt att gemensamt bekämpa människohandel. Det är viktigt att få politiskt stöd och resurser för att aktivt kunna motverka människohandel i Norden.

\section{Rekommendationer}

- Samarbete mellan olika myndigheter, både nationellt och internationellt.

- Fokus på penningtransaktioner i den brottsliga verksamheten "follow the money".

- Utbildning av de aktörer som är och kan komma i kontakt med människohandel.

- Fokus på hjälp åt offren.

\subsection{Diskussion}

Under diskussionen väcktes frågor bl.a. gällande de expertvittnen som används i Norge. Med tanke på att offren ibland är medvetna om att de kommer att arbeta med dåliga arbetsvillkor och på så sätt kan anses ha givit sitt samtycke ifrågasattes förekomsten av tvång under diskussionen. Som svar på detta konstaterades att offrets samtycke saknar bety- 
delse och friar inte från ansvar om ett otillbörligt medel använts för att få samtycket. Förövarna har oftast varit utlänningar som utnyttjat sina landsmän. Det är lättare att utnyttja personer som inte känner till landets lagstiftning och bestämmelserna om anställningsvillkor och därför rekryteras utländsk arbetskraft. För rekryteringen behövs kontakter vilket de utlänningar som redan bor i landet har.

\subsection{Sessionens rekommendationer}

- Utnyttja expertvittnen under rättegången för att belysa helhetssituationen vid människohandel.

- Aktivt föra fall vidare, till sist lyckas det. Kunskapen och medvetenheten ökar med tiden.

- Starkt samarbete mellan polis, åklagare och arbetarskydd.

- Poliser specialiserade i utredning av människohandel.

- Samarbetsavtal för rättshjälp. 


\section{Session IV Lever Norden som den lär?}

Målsättningen med sessionen var att fokusera på bland annat följande frågor:

- Vem faller offer för människohandel?

- Hur ser offren själva på sin situation?

- Vad behöver offren, hurudan hjälp?

- Hurudan hjälp erbjuds offren i dagsläget?

- Lever Norden som den lär?

- Vad kan de nordiska länderna göra för att bekämpa arbetsrelaterad människohandel? Hur kan offrens rättigheter tryggas?

\section{Ordförande Birgitte Ellefsen, Høgskolelektor och PhD stipendiat, Politihøgskolen, Norge}

Högskolelektor och forskare Birgitte Ellefsen konstaterade att de nordiska länderna internationellt poängterat vikten av att säkra offrens rättigheter till bistånd och skydd. Trots detta kunde Ellefsen konstatera att forskning och rapporter från medborgarorganisationer visar att manliga människohandelsoffer inte erbjuds lika mycket bistånd som kvinnliga offer i Norden. Åtgärder för att identifiera och beskydda offer som utnyttjas för tiggeri, narkotikaförsäljning, stölder och annan kriminell verksamhet bör också vidtas. Dessutom betonade Ellefsen att människohandel inte enbart skall ses som social dumpning eller en kränkning av arbetsrättsliga bestämmelser utan som en kränkning av de mänskliga rättigheterna. Detta har avgörande betydelse för att offrets rättigheter till bistånd och beskydd skall förverkligas. 


\subsection{Drömmen om utbildning och jobb}

\section{Direktör Sirle Blumberg, Living for Tomorrow, Estland}

Direktör Sirle Blumberg redogjorde om den utveckling i arbetet mot människohandel som skett under de senaste åren i Estland. Bland annat intogs människohandel som egen straffbestämmelse i estnisk lagstiftning år 2012, vilket betydde ett stort framsteg för Estland. Blumberg beskrev även organisationens Living for Tomorrow verksamhet. Organisationen arbetar med att hjälpa personer som blivit offer för människohandel både i Estland och utomlands. Organisationen mottar ca 600 telefonsamtal årligen. $70 \%$ av samtalen gäller arbetskraftsutnyttjande i Estland, och resten gäller utnyttjande av arbetskraft i andra länder. Offren är kvinnor ovh män mellan 30-55 år, med grund- eller högre utbildning och som har lån och skulder. Personer från Estland reser till följande länder för att finna arbete: Finland, Tyskland, Sverige, Norge och Ryssland. Enligt Blumberg har det förekommit problem med privata arbetsförmedlingsbyråer, som har kräft olagliga avgifter för arbetsförmedlingen. Det är även problem med de arbetsgivare som inte undertecknat kollektivavtal.

\section{Rekommendationer}

- Bättre övervakning av privat arbetsförmedlingsbyråer.

- Kollektivavtalen borde gälla alla arbetsgivare.

\subsection{Vem kommer till Sverige för att jobba?}

\section{Enhetschef Arto Moksunen, Crossroads, Sverige}

Enhetschef Arto Moksunen presenterade Crossroads verksamhet i Sverige. Crossroads är ett EU-finansierat samarbetsprojekt för att motverka socialt utförandeskap och fattigdom. Crossroads erbjuder samhällsinformation, arrangerar olika kurser (språk, IT, arbetsökning, matlagning) och ger rådgivning och juridisk hjälp men förmedlar inte arbete eller bostäder. De personer som söker sig till Crossroads har kommit till Sverige för att de önskar att hitta ett arbete, få samhällsinformation på sitt eget språk, ha personlig kontakt med anställda, delta i kursverksamhet och skaffa ett boende. Deras föreställningar om Norden är att i de nordiska länderna finns det arbete och bostäder, och att samhället fungerar 
och man blir gott bemött. Den främsta orsaken till att komma till Norden är att personerna inte har en chans att hitta ett jobb i sitt eget hemland.

\section{Rekommendationer}

- Statistik är en bra metod för att samla in baskunskaper om de personer som kommer till Norden.

- Erbjuda samhällsinformation i varje land till arbetsimmigranter

- Utveckla kontakt med avsändarländerna.

- Samarbete över gränserna.

- Utveckla organiserad återvandring.

\subsection{Reflektionsperioder för människohandelsoffer - erfarenheter från sju länder}

\section{Forskare Anette Brunovskis, Institutt for Arbeidslivs-og velferdsforskning (FaFo), Norge}

Forskare Anette Brunovskis presenterade sin forskning om reflektionsperioder för människohandelsoffer. En reflektionsperiod innebär ett tillfälligt uppehållstillstånd, som beviljas offer för människohandel, som saknar permanent uppehållstillstånd. Syftet med reflektionsperioden är att hjälpa offret och att uppmuntra offren till samarbete med myndigheterna. De länder som undertecknat Europa rådets konvention, måste bevilja människohandelsoffer en reflektionsperiod, men längden på perioden, samt grunderna för hur de beviljas, kan variera från land till land. Enligt forskningen finns det fördelar med både längre och kortare reflektionsperioder. De kortare perioderna fyller polisens behov medan de längre perioderna är bättre för offren. Sammanfattningsvis konstaterade Brunovskis att reflektionsperioderna och de olika modeller som finns idag har både fördelar och nackdelar. Perioderna kan ses som en kompromisslösning i brist på bättre processer. 


\section{Rekommendationer}

- Viktigt att alla aktörer, som kommer i kontakt med människohandelsoffer, kan identifiera offren och ansöka om reflektionstid för dem.

- Viktigt att hitta en balans mellan att erbjuda hjälp till offren och kravet på att offren samarbetar med myndigheterna. Vissa offer kan ha väldigt lite information om förövarna och detta skall inte vara ett hinder för att få hjälp.

\subsection{Kommentar}

\section{Advokat Emilia Kaikkonen, Advokatbyrå Matti Penttinen Ab,} Finland

Advokat Emilia Kaikkonen redogjorde för de erfarenheter som hon erhållit genom att biträda människohandelsoffer i rättegångar. Offrens respekt för auktoriteter, känslan av att man inte skall klaga på "små" problem och tanken om att det är pinsamt att ha blivit utnyttjad beskrev Kaikkonen som ofta hindrar offren från att medge att de har blivit utnyttjade. Kaikkonen konstaterade även att det för offren inte alltid är viktigt med hur det går i straffprocessen. Offrens behov är mer praktiska, som att ha ett tryggt boende. Advokater kan främst erbjuda offren för människohandel hjälp med att ansöka om uppehållstillstånd, kräva ersättning och framställa lönekrav.

\section{Rekommendationer}

- Viktigt att offren alltid erbjuds rättshjälp.

- Under förhören i förundersökningen behövs rätt förhörsteknik och rätta frågor, för att förhöret skall lyckas. Genom att utnyttja olika förundersökningsmetoder och tvångsmedel kan man få bevisföring som garanterar bättre framgång i rätten.

- Olika parter behöver mer omfattande kunskaper om innehållet i brottsrekvisitet människohandel.

- En attitydförändring bland allmänheten om människohandel och offrens situation behövs. En allmän uppfattning är att offret borde ha tagit reda på om villkoren för arbete. 


\subsection{Sessionens rekommendationer}

- Mera forskning om människohandel för att erhålla fakta om människohandel.

- Mera utbildning om identifiering av offren.

- Flera preventiva insatser behövs, för att t.ex. minska på efterfrågan.

- Hjälpen till offren är viktig - erbjud offren rättshjälp, ge dem information om samhället och erbjud offren en möjlighet att resa hem.

- Samarbetet mellan olika aktörer i ursprungslandet och mottagarlandet borde förbättras.

Bild 3. Deltagarna lyssnade uppmärksamt till talarna i sessionen om Lever Norden som den lär?

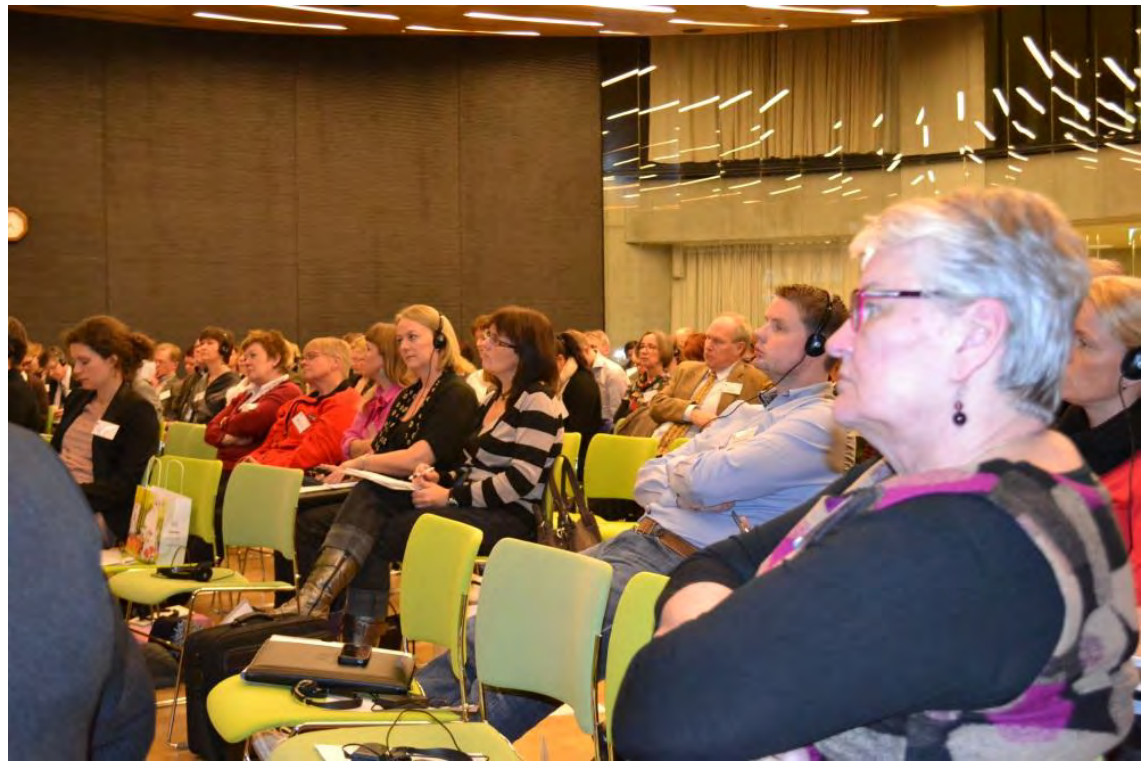

Fotograf: Matti Keränen. 



\section{Session V Paneldiskussion Samarbete över gränser}

\section{Ordförande}

Överinspektör Måns Enqvist, Minoritetsombudsmannens byrå, Helsingfors, Finland.

\section{Panelen}

- Seniorrådgivare Maria-Pia de Palo, Nordiska ministerrådet

- Kammaråklagare Christina Voigt, Internationella åklagarkammaren, Stockholm, Sverige.

- Vicepolitikommisær Trine Møller, Københavns Politi, Danmark.

- Polisinspektör Berglind Eyjólfsdóttir, Reykjavik polis, Island.

- Enhetschef Arto Moksunen, Crossroads Stockholm, Sverige.

- Utbildningspolitisk sakkunnig Mikko Koskinen, Servicefacket PAM ry, Helsingfors, Finland.

Varje panelmedlem blev ombedd att ge goda exempel och erfarenheter på sätt att förbättra bekämpningen av människohandel.

Nedan följer en presentation av medlemmarnas förslag på lösningar.

\section{Christina Voigt}

Skapa attitydförändringar genom massmedial uppmärksamhet. Den massmediala uppmärksamheten som fallet med bärplockarna fick i Sverige ledde till en attitydförändring bland allmänheten gentemot bärplockarna, vilket underlättade utredningen och arbetet att identifiera bärplockarna som offer för människohandel. 


\section{Mikko Koskinen}

Fackorganisationerna borde engagera sig i en samhällsinsats som Crossroads genom att samarbeta med olika aktörer. Fackorganisationernas tankesätt behöver förändras. Övervakningen av de mest sårbara arbetstagarnas rättigheter hör även till fackets uppgifter och kan inte enbart ses som välgörenhet. Koskinen påpekade också att det behövs en förståelse för nya trender inom arbetsmarknaden.

\section{Trine Moller}

Att våga tänka utanför ramen är viktigt för att bekämpa människohandel och för att få fler fall behandlade i domstol.

\section{Maria-Pia de Palo}

Det är viktigt med regionalt och nordiskt tvärsektoriellt samarbete och med samarbete mellan mottagar- och avsändarland. Det är också viktigt att se på människohandel utgående från ett könsperspektiv, män och kvinnor behöver hjälp och tjänster av olika slag.

\section{Berglind Eyjólfsdóttir}

Island har så lite erfarenhet av människohandel att för dem är det viktigast att utnyttja erfarenheterna i andra länder för att öka den nationella kunskapen. Det nordiska samarbetet är en viktig plattform för gemensamma insatser.

\section{Arto Moksunen}

Det är viktigt att knyta kontakter och samarbeta med europeiska länder. En bra lösning är att skapa nätverk inom vilka myndigheter och medborgarorganisationer samarbetar, enligt Crossroads modell. Ingen kan ensam lösa problemen gällande människohandel. 
Bild 4. Överinspektör Måns Enqvist ledde paneldiskussionen. I panelen deltog (sittande från vänster): kammaråklagare Christina Voigt, Sverige, utbildningspolitisk sakkunnig Mikko Koskinen, Finland, seniorrådgivare Maria-Pia de Palo, Nordiska ministerrådet, vicepolitikommissær Trine Møller, Danmark, polisinspektör Berglind Eyjólfsdóttir, Island och enhetschef Arto Moksunen, Sverige

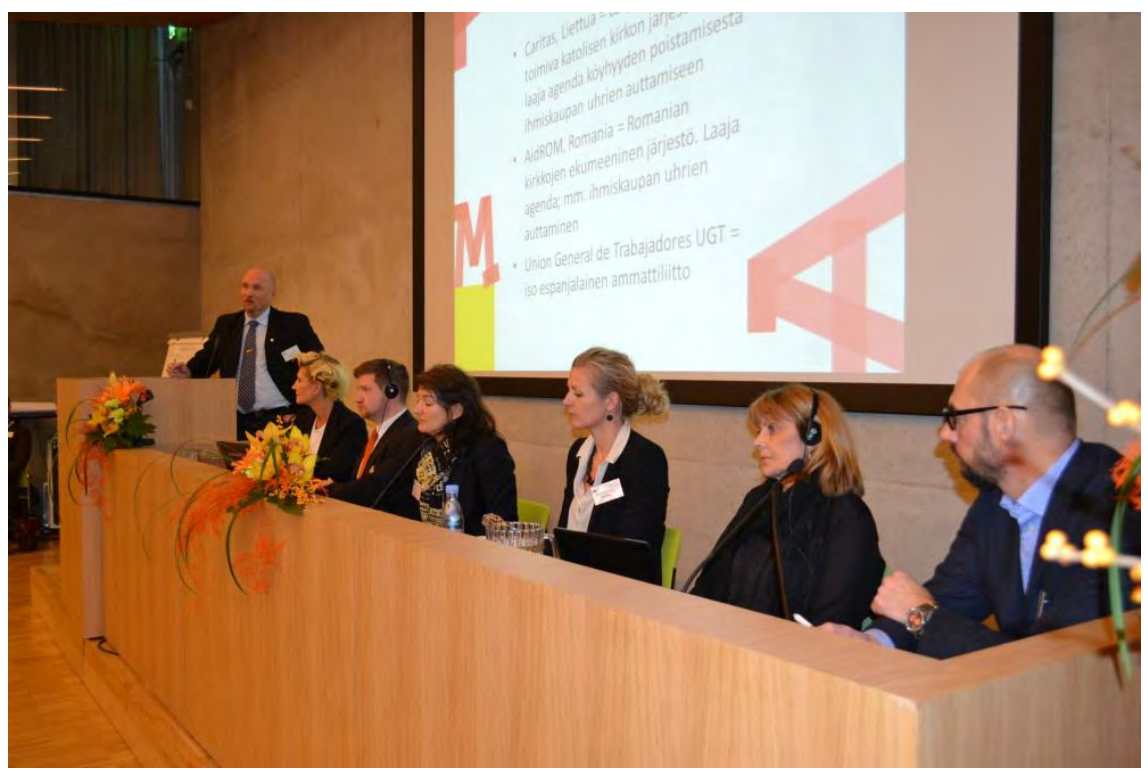

Fotograf: Matti Keränen. 



\section{Uppsummering och avslutning}

Minoritetsombudet och den nationella människohandelsrapportören Eva Biaudet sammanfattade de mest centrala slutsatserna från konferensen.

Offren är svåra att hitta om de inte själva ber om hjälp. Detta ställer krav på ökad kunskap hos myndigheter och övriga aktörer som kommer i kontakt med offer, för att ha bättre verktyg att identifiera offren.

Det får inte glömmas att reflektionsperioderna finns till för att människohandelsoffren skall kunna återhämta sig. Reflektionsperioderna skall inte bli ett sätt att pressa offret till samarbete med myndigheterna för att få framgång i behandlingen av fallet i rättsprocessen.

Det finns ett behov för könsspecifik hjälp till offren. Män och kvinnor har olika behov som bör beaktas vid utarbetande av hjälpsystem för offer.

Hjälpen skall inte enbart begränsas till identifierade offer. Det behövs aktiviteter som Crossroads verksamhet, som även erbjuder personer som inte identifierats som offer för människohandel, hjälp för att integreras i samhället.

En nationell människohandelsrapportör eller motsvarande organ behövs för att utvärdera om lagstiftningen fungerar och som har i uppgift att analysera nuläget och ta upp problemområden.

För att kunna dra nytta av nordiskt och internationellt samarbete är det viktigt att komma ihåg att människohandeln är likadan i alla länder oberoende av olika lagstiftningsmodeller. 



\section{Sammanfattning av rekommendationerna}

\subsection{Allmänna}

- Kunskapen om arbetsrelaterad människohandel är för tillfället bristfällig, frågan måste prioriteras och kunskapen ökas för identifiering av människohandel. Detta förutsätter politisk vilja.

- Förstå att arbetsrelaterad människohandel är en del av migrationsbrottslighet.

- Människohandel och utnyttjande av arbetskraft bör ses i ett större sammanhang. Sätt fokus på nyanserna i debatten om människohandel och urvattna inte begrepp och definitioner. Allt är inte människohandel. Alla bör inse den risk det finns att en situation kan utvecklas till människohandel i ett senare skede.

- En attitydförändring bland allmänheten om människohandel och offrens situation behövs. En allmän uppfattning är att offret borde ha tagit reda på om villkoren för arbetet.

- Mera utbildning för de personer inom polis, gränsbevakning, arbetarskydd, social- och hälsovården som kan komma i kontakt med människohandelsoffer för att förbättra identifieringen av offer. Informationsutbyte och gemensamma spelregler är en förutsättning för identifiering av offren.

- Respekt av människovärdet och de mänskliga rättigheterna i behandlingen av offret, utveckling av hjälpsystemet för offer, bättre uppföljning av offrens situation och åtgärder för att offer inte på nytt blir offer för människohandel.

- Män och kvinnor behöver hjälp och tjänster av olika slag och det är viktigt att skräddarsy åtgärder för kvinnor och män. Idag behövs det utvecklas hjälpsystem och tjänster som är riktade till män.

- Insatserna bör inte koncentreras till att hitta och avslöja människohandel inne i ett enskilt land - utan det skall stoppas redan vid gränsen. 
- Minska efterfrågan.

- Mera diskussion om uppehållstillstånd.

- Mera forskning om människohandel för att erhålla fakta om människohandel.

\subsection{Rekrytering och övervakning}

- Öka myndighetssamarbete för övervakning och kontroll av rekryteringsfirmor, privata arbetsförmedlingar och arbetsplatser för att minska utnyttjandet av arbetskraft och öka risken för att bli avslöjad.

- Ansvaret hos huvudentreprenören bör betonas starkare. Huvudentreprenerören har ansvar för det som underleverantörerna förmedlar. Livsmedelsindustrin bör ta ett ansvar genom att kontrollera att bärplockarnas arbetsvillkor och löner följer landets gällande regler.

- Inom bärplockningsbranschen borde myndigheterna bättre övervaka finansieringen av bärplockningsresorna och bärplockarnas beroende av rekryteringsfinansieringen borde minskas. De verkliga inkomsterna och kostnaderna bör kunna följas upp.

Rekryteringskostnaderna får inte bli för höga och förtjänsten bör fördelas jämnare mellan bärplockarna, rekryterarna och företagen, som köper upp bären.

- Mera tillgänglig information om arbetstagarens rättigheter och skyldigheter i arbetssökarnas hemländer på arbetstagarnas språk, t.ex. då de ansöker om uppehållstillstånd.

- Regelbunden och omfattande övervakning av arbetsplatser också i förebyggande syfte. Under granskningarna kan inspektören upplysa arbetstagarna om lagar och kollektivavtal och om arbetstagarnas rättigheter och arbetsgivarens skyldigheter.

- Införa krav på att alla arbetare på arbetsplatsen skall bära id-kort med deras skattenummer.

- Enklare regelverk för arbetsinvandringen. 


\subsection{Rättsprocesser}

- Inrätta specialiserade förundersökningsmyndigheter för människohandel.

- Starkt samarbete mellan polis, åklagare och arbetarskydd.

- Låg tröskel för att förnya verksamheten och strategierna. Våga ta itu med problemet och ge inte upp trots att processen är svår och tung.

- Snabbare förundersökningar.

- Under förhören i förundersökningen behövs rätt förhörsteknik och rätta frågor, för att förhöret skall lyckas. Genom att utnyttja olika förundersökningsmetoder och tvångsmedel kan man få bevisföring som garanterar bättre framgång i rätten.

- Vara lyhörd på vad offren berättar och ha förståelse för offrets situation. Berättar de samma historia och bildar det ett mönster om människohandel. Kom ihåg: "I will only tell my story if you care about it".

- Viktigt att genast isolera gärningsmannen och de eventuella offren från varandra, med hjälp av hjälpsystemet för människohandelsoffer eller genom att begära gärningsmannen häktad.

- Viktigt att offren alltid erbjuds rättshjälp. Viktigt att hitta en balans mellan att erbjuda hjälp till offret och krav på att offren samarbetar med myndigheterna. Vissa offer kan ha väldigt lite information om förövarna och detta skall inte hindra dem från att få hjälp

- Användning av expert-vittnen under rättegången.

- Införa användning av simultantolkningen under rättegångar för att förkorta behandlingstiden.

- Etablera nationella "task force".

- Sänka tröskeln för anmälning till polisen.

- Olika parter behöver djupare kunskap om innehållet i brottsrekvisitet människohandel.

- Hela systemet för att bekämpa grå ekonomi måste utvecklas. 


\subsection{Samarbete}

- Tvärsektoriellt och -regionalt samarbete är en förutsättning för att bekämpa människohandel. Människohandel är inte ett enskilt lands angelägenhet - enbart nationella åtgärder kan inte bekämpa människohandel. Både arbetarskyddet och polisen måste utföra mer uppsökande arbete för att identifiera offer. Utse en nordisk grupp för utbyte av erfarenheter.

- Samarbete mellan myndigheter både på nationell, nordisk och internationell nivå.

- Samarbete mellan ursprungs- och destinationslandets myndigheter.

- Samarbete och utbyte av information mellan åklagare som arbetar med människohandel i Norden.

- Flera parter måste samarbeta redan i rekryteringen av arbetskraft industri, fack, myndigheter.

- Tvärsektoriellt informationsutbyte och dokumentation.

Bild 5. Minoritetsombudet Eva Biaudet presenterade en sammanfattning och avslutade konferensen

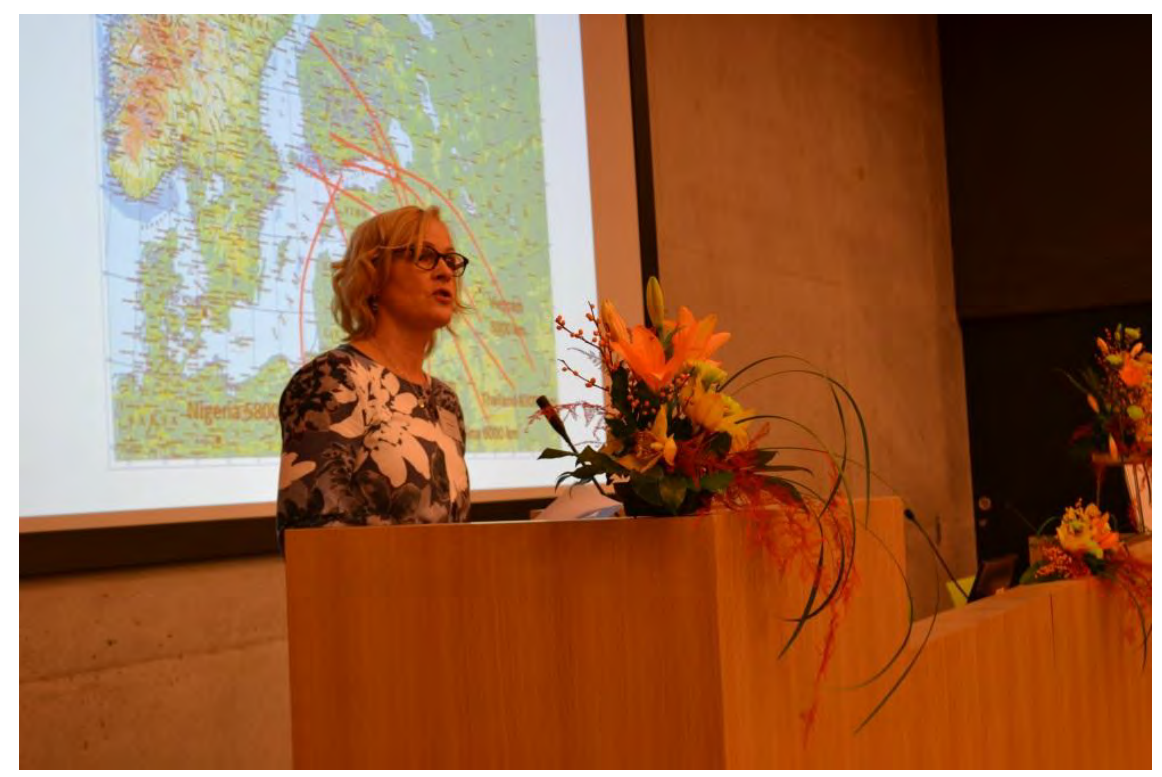

Fotograf: Matti Keränen. 


\section{Summary}

The Nordic conference on Human Trafficking and Working Life was arranged in Helsinki, Finland 27-28.11.2013. The Nordic conference focused on how people today become victims of human trafficking as they seek jobs in foreign countries. The aim of the conference was to raise awareness of problems attached to this form of human trafficking in the Nordic countries through a diversified perspective.

The greatest challenge for Nordic stakeholders today is to identify the persons - women, men, girls and boys - who are victims of labour trafficking. It is also important that victims receive information about their rights, and about the social services that are available to them. A key question is how to adapt social services to the needs of the victims. At the conference practical examples was presented of how the Nordic countries, police, prosecutors, courts, occupational safety authorities, labour market organizations and NGOs' work with issues concerning human trafficking and the labour market in the Nordic countries.

The conference was built on the results and experiences obtained from other recent conferences and projects undertaken by Nordic Council of Ministers and authorities and organizations in the Nordic countries on the subject of human trafficking and working life.

Important questions discussed during the conference were:

- What is the difference between being forced to work and the poor working conditions some immigrants face?

- What is the greatest challenge in terms of identifying victims of trafficking at the labour market?

- How can the occupational safety authorities contribute?

- How can co-operation between the authorities and labour market organizations be intensified? Which are the greatest challenges?

- Are the social services consistent with the needs of the victims?

- What can be achieved through Nordic co-operation? 
During the conference was arranged:

- An opening session

- Four theme sessions

To the Nordic countries - recruiting labour force, Human trafficking exploitation of the labour force in the Nordic countries, Legal proceedings - human trafficking and the labour market and Do the Nordic countries practise what they preach?

- A panel discussion

- Ombudsman for Minorities Eva Biaudet closed the conference by giving a summary of the conference.

Ombudsman for Minorities Eva Biaudet closed the conference by giving a summary of the conference.

All speakers presented recommendations for future actions and measures to combat labour trafficking. The speakers' recommendations are included in their presentations. In the end of the conference report there is a summary of the recommendations presented at the conference.

The conference drew approximately 260 participants from different countries and organizations throughout the Nordic countries, the Baltic countries and Russia. Included among the participants were 70 representatives from police/law enforcement and border security. Other participants included politicians, international organizations, public prosecutors, immigration authorities, occupational health and safety authorities, trade unions and employer's organizations, NGOs and researchers.

The conference was arranged by the Ombudsman for Minorities in Finland. The conference was financed by the Nordic Council of Ministers in co-operation with the Ombudsman for Minorities in Finland and the Nordic Council. The Ombudsman for Minorities is the national rapporteur on trafficking in human beings in Finland. 


\title{
9. Bilaga 1
}
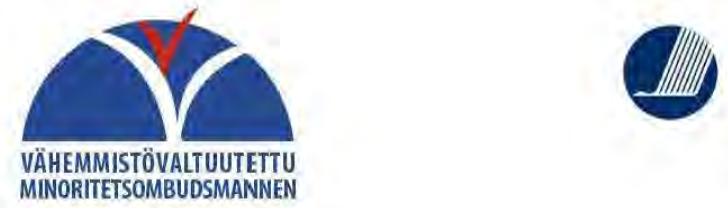

norden

Nordiska ministerrådet

16.11 .2012

\author{
NORDISK KONFERENS MED FOKUS PÅ MÄNNISKOHANDEL OCH \\ ARBETSLIV \\ Sirkus-salen, Paasitorni, Paasivuorigatan 5, Helsingfors \\ 27-28 november 2012
}

Den nordiska konferensen Människohandel med fokus på arbetslivet skall diskutera och fokusera på hur personer idag blir offer för människohandel när de söker sig till andra länder för att få ett arbete. Målet med konferensen är att lyfta upp kunskap om problem som är kopplade till denna form av människohandel $\mathrm{i}$ Norden $\mathrm{i}$ ett tvärsektoriellt perspektiv.

Största utmaningen för de olika aktörerna i Norden idag är att identifiera de personer, kvinnor, män, flickor och pojkar, som är offer för arbetsrelaterad människohandel. Det är även viktigt att offren erhåller information om sina rättigheter, men också om de sociala tjänster som finns tillgängliga för dem. En viktig fråga är hur de sociala tjänsterna är anpassade till offrens behov.

Målet är att förmedla information om olika aktörers kunnande, roller, ansvar och förmåga att identifiera och hantera problemen kring arbetsrelaterad människohandel. Konferensen skall ta utgångspunkt i resultat och erfarenheter från konferenser och projekt, som myndigheter och organisationer i Norden genomför och har genomfört, kring prolemställningar om människohandel och arbetslivet under de senaste åren.

På konferensen presenteras praktiska exempel på hur de nordiska länderna, polisen, åklagare, domstol, arbetarskyddsförvaltning, arbetsmarknadsparter och NGOs arbetar med människohandel kopplat till arbetsmarknaden i Norden. 
Frågeställningar viktiga att diskutera på konferensen är:

- Vad är skillnaden mellan att bli tvingad att arbeta och dåliga arbetsvillkor, som en del invandrare hamnar i?

- Vad är den största utmaningen gällande identifieringen av offer för människohandel inom arbetsmarknaden?

- Vad kan arbetarskyddet bidraga med?

- Hur kan samarbetet mellan myndigheter och arbetsmarknadens parter effektiveras? Vilka är de största utmaningarna?

- Är de sociala tjänsterna anpassade till offrens behov?

- Vad uppnås genom ett nordiskt samarbete?

Konferensspråket är främst skandinaviska och med tolkning till finska, engelska och ryska.

Konferensen arrangeras av Minoritetsombudet i Finland, i samarbete och med finansiering av Nordiska ministerrådet och Nordiska rådet. Minoritetsombudet i Finland är den nationella rapportören för människohandel.

\section{PROGRAM}

TISDAG 27.11.2012

\subsection{Registrering och lunch}

\subsection{0 ÖPPNING AV KONFERENSEN}

Ordförande: Minoritetsombud Eva Biaudet, Finland

Minister Anna-Maja Henriksson, Justitieministeriet, Finland Generalsekreterare Halldor Asgrimsson, Nordiska ministerrådet Riksdagsledamot Satu Haapanen, Riksdagen, Finland och ordförande för Medborgar- och konsumentutskottet, Nordiska Rådet

13.30 Människohandel - vad är tvång, vad är utnyttjande? Minoritetsombud Eva Biaudet, Finland 
14.00 SESSION I: TILL NORDEN - REKRYTERING AV ARBETSKRAFT

(CBSS)

Ordförande: Seniorrådgivare Anna Ekstedt, Östersjörådet

Rekrytering av sjukskötare till Ullevål sjukhus i Oslo

Polisinspektör Bjørn Vandvik, Utlendings- og forvaltningsseksjonen, Oslo politidistrikt, Norge

Utländska bärplockare i Finland fors, Finland

Forskare Pekka Rantanen, Tammerfors universitet, Tammer-

Menneskehandel blandt au pairs og i rengøringsbranchen - risiko, rekruttering og mellemmænd

Antropolog, PhD-stipendiat Trine Mygind Korsby, Institut for

Antropologi, Köpenhamns universitet, Köpenhamn, Danmark

Kommentar:

2dra ordförande Kyösti Suokas, Byggnadsförbundet, Finland

Diskussion

15.30 Kaffepaus

\subsection{SESSION II: MÄNNISKOHANDEL - UTNYTTJANDE AV}

ARBETSKRAFT I NORDEN

Ordförande: Riksdagsledamot Maria Stenberg, Riksdagen, Sverige, och Medborgar- och konsumentutskottet, Nordiska Rådet

Arbetskraftsinvandring från Öst- och Central-Europa till Norden: mönster, arbetsförhållanden och rekrytering

Forskare Line Eldring, Institutt for Arbeidslivs-og velferdsforskning (FaFo), Norge

Menneskehandelns bagmæend - skats indsatser mot menneskehandel

John Vorbeck Petersen, Økonomisk kriminalitet, Skat, Danmark

Fackets insatser att bekämpa människohandel på arbetsmarknaden i Norden

Migrationspolitisk expert, utredare Thord Ingesson, LO, Sverige

Kommentar: Inspektör Kristiina Linna, Regionförvaltningsverket i Sydvästra Finland, ansvarsområdet för arbetarskydd, Finland 
17.30 Avslutning och uppsummering

Minoritetsombud Eva Biaudet, Finland

18.30 Mottagning

Ständerhuset, Snellmansgatan 9-11, Helsingfors

\section{ONSDAG 28.11.2012}

\subsection{SESSION III: RÄTTSLIGA PROCESSER - MÄNNISKOHAN-}

\section{DEL OCH ARBETSLIVET}

Ordförande: Specialplanerare Natalia Ollus, Europeiska institutet för kriminalpolitik, verksamt

i anslutning till Förenta Nationerna, HEUNI, Finland

Norska rättsfall - samarbete mellan åklagare och polis

Avsnittsleder Jarle Bjørke, BSP/Org.Krim Analyse \& Ko-

ordineringsavsnittet,

Hordaland politidistrikt, Norge till Sverige

Människohandel med bärplockare - rekrytering av bärplockare

Kammaråklagare Christina voigt, Internationella åklagarkam-

maren, Stockholm, Sverige

Arbetsrelaterad människohandel - utmaningar i förundersökning och process sett med

åklagarens ögon

Ledande häradsåklagare Peter Levlin, Åklagarämbetet i Österbotten, Finland

Kommentar:

Distrikt polis kommissarie Sigríur Björg Guðjónsdóttir, Suðurnes polisdistrikt, Island 


\subsection{SESSION IV: LEVER NORDEN SOM DEN LÄR?}

Ordförande: Høgskolelektor och phd stipendiat Birgitte Ellefsen, Politihøgskolen, Norge

Drömmen om utbildning och jobb

Sirle Blumberg, Living for Tomorrow, Estonia

Vem kommer till Sverige för att jobba?

Enhetschef Arto Moksunen, Crossroads, Sverige

Refleksjonsperioder for ofre - erfaringer fra syv land

Forskare Anette Brunovskis, Institutt for Arbeidslivs-og vel ferdsforskning (FaFo), Norge

Kommentar: Advokat Emilia Kaikkonen, Finland

Diskussion

13.00 Lunch

14.00 SESSION V: PANELDISKUSSION - SAMARBETE ÖVER GRÄNSER OCH SEKTORER

15.30 UPPSUMMERING OCH AVSLUTNING

Minoritetsombud Eva Biaudet, Finland 
Nordiska ministerrådet

Ved Stranden 18

DK-1061 København K

www.norden.org

\section{Människohandel och arbetsliv}

Den nordiska konferensen Människohandel med fokus på arbetslivet diskuterade hur personer idag blir offer för människohandel när de söker sig till andra länder för att få ett arbete. Målet för konferensen var att lyfta upp kunskap om problem som är kopplade till människohandel och arbetsliv i Norden i ett tvärsektoriellt perspektiv.

Största utmaningen i Norden idag är att identifiera de personer, kvinnor, män, flickor och pojkar, som är offer för arbetsrelaterad människohandel. Det är viktigt att offren erhåller information om sina rättigheter, och om de sociala tjänster som finns tillgängliga för dem, och hur de sociala tjänsterna är anpassade till offrens behov.

Konferensen mål var att förmedla information om olika aktörers kunnande, roller, ansvar och förmåga att identifiera och hantera problemen kring arbetsrelaterad människohandel. Konferensen tog utgångspunkt i de resultat och erfarenheter som myndigheter och organisationer i Norden idag.

På konferensen presenterades praktiska exempel på hur de nordiska länderna, polisen, åklagare, domstol, arbetarskyddsförvaltning, arbetsmarknadsparter och NGOs arbetar med människohandel kopplat till arbetsmarknaden i Norden.
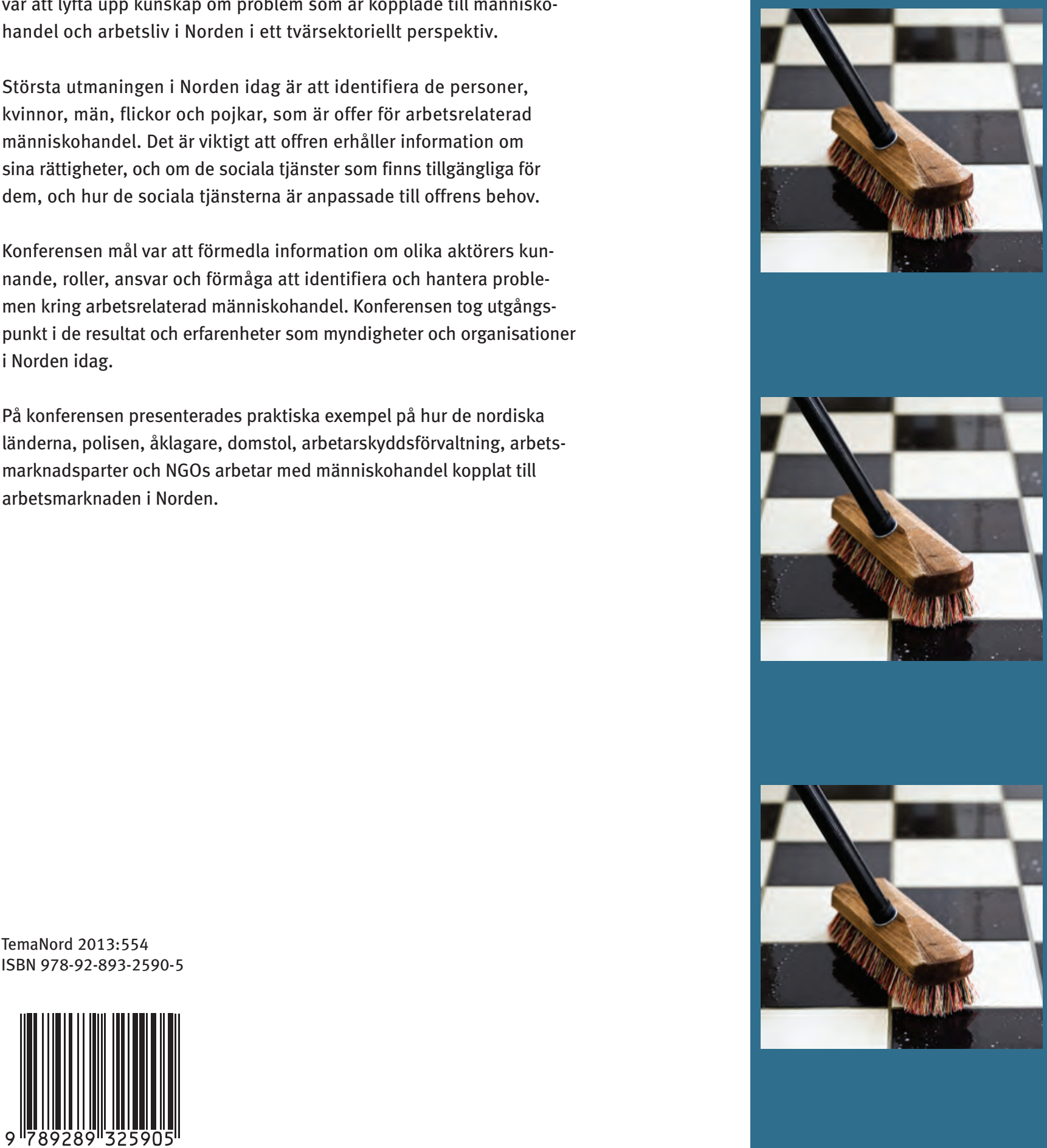